\title{
Article \\ Global Transcriptome Profile of the Oleaginous Yeast Saitozyma podzolica DSM 27192 Cultivated in Glucose and Xylose
}

\author{
Habibu Aliyu *(D), Olga Gorte, Anke Neumann (1D) and Katrin Ochsenreither *(D)
}

check for updates

Citation: Aliyu, H.; Gorte, O.; Neumann, A.; Ochsenreither, K. Global Transcriptome Profile of the Oleaginous Yeast Saitozyma podzolica DSM 27192 Cultivated in Glucose and Xylose. J. Fungi 2021, 7, 758. https:// doi.org/10.3390/jof7090758

Academic Editor: Sotiris Amillis

Received: 19 August 2021

Accepted: 13 September 2021

Published: 15 September 2021

Publisher's Note: MDPI stays neutral with regard to jurisdictional claims in published maps and institutional affiliations.

Copyright: (c) 2021 by the authors. Licensee MDPI, Basel, Switzerland. This article is an open access article distributed under the terms and conditions of the Creative Commons Attribution (CC BY) license (https:// creativecommons.org/licenses/by/ $4.0 /)$.
Institute of Process Engineering in Life Science 2: Technical Biology, Karlsruhe Institute of Technology, 76131 Karlsruhe, Germany; olga.gorte@gmail.com (O.G.); anke.neumann@kit.edu (A.N.)

* Correspondence: habibu.aliyu@kit.edu (H.A.); katrin.ochsenreither@kit.edu (K.O.)

\begin{abstract}
Unlike conventional yeasts, several oleaginous yeasts, including Saitozyma podzolica DSM 27192, possess the innate ability to grow and produce biochemicals from plant-derived lignocellulosic components such as hexose and pentose sugars. To elucidate the genetic basis of $S$. podzolica growth and lipid production on glucose and xylose, we performed comparative temporal transcriptome analysis using RNA-seq method. Approximately 3.4 and $22.2 \%$ of the 10,670 expressed genes were differentially (FDR $<0.05$, and $\log 2 \mathrm{FC}>1.5$ ) expressed under batch and fed batch modes, respectively. Our analysis revealed that a higher number of sugar transporter genes were significantly overrepresented in xylose relative to glucose-grown cultures. Given the low homology between proteins encoded by most of these genes and those of the well-characterised transporters, it is plausible to conclude that $S$. podzolica possesses a cache of putatively novel sugar transporters. The analysis also suggests that $S$. podzolica potentially channels carbon flux from xylose via both the non-oxidative pentose phosphate and potentially via the first steps of the Weimberg pathways to yield xylonic acid. However, only the ATP citrate lyase (ACL) gene showed significant upregulation among the essential oleaginous pathway genes under nitrogen limitation in xylose compared to glucose cultivation. Combined, these findings pave the way toward the design of strategies or the engineering of efficient biomass hydrolysate utilization in S. podzolica for the production of various biochemicals.
\end{abstract}

Keywords: glucose; microbial lipid; oleaginous yeast; RNA-seq; Saitozyma podzolica DSM 27192; sugar transporters; Weimberg pathway; xylose

\section{Introduction}

According to the forecast of the United Nations, the world's population is expected to grow by $\sim 20 \%$ to 9.7 billion people within the next 30 years [1]. The demand for energy and material resources will therefore also increase. To satisfy these requirements and to circumvent economic and environmental challenges, which are associated with reliance on fossil sources, renewable and sustainable energy sources need to be developed. Microbial lipids produced by oleaginous yeasts could contribute as one of the numerous alternative energy sources. Oleaginous yeasts are able to accumulate up to $70 \%$ of their cell dry mass to the storage lipids, mainly triacylglycerols [2]. As a carbon source, yeasts are able to metabolize a large spectrum of cheap and abundant raw materials, such as lignocellulosic plant biomass or waste from the agricultural and food industry, enabling carbon recycling within a biorefinery concept [3-5]. Moreover, yeast cell propagation proceeds with high duplication rates and the cultivation can be easily upscaled, in contrast to microalgae. In addition, yeast cultivation is independent of season, climate and location, which is highly advantageous compared to oil seeds [6,7]. However, the molecular and evolutionary mechanisms of oleaginicity in yeasts remain unclear. By phylogenetic comparisons of oleaginous yeasts, it becomes apparent that often the property of oleagenicity is not shared 
by distinct phylogenetic groups [8,9]. Thus, this characteristic cannot be identified by pedigree analyses and is still the subject of current research.

For lipid production by oleaginous yeasts, two pivotal conditions are essential to the cultivation process, namely, carbon excess and nutrient limitation, mostly nitrogen. The latter induces lipid synthesis and intracellular accumulation for energy storage [2]. Usually, a two-stage process is performed comprising a first nutrient-rich phase for cell mass formation and merging into a nitrogen deficient stage with excess carbon source [10-13]. To avoid the highly controversial "food-or-fuel" debate, renewable and sustainable carbon sources should be used for microbial lipid production. For that purpose, plant biomass is a potential candidate containing polymers of cellulose and hemicellulose with glucose and xylose as the most abundant constituent monosaccharides [14]. Therefore, the molecular transport and metabolism of these hexose and pentose sugars in oleaginous yeasts needs further clarification.

Saitozyma podzolica DSM 27192, isolated from peat bog soil in Karlsruhe, Germany [15], produces microbial lipid under nitrogen limitation and sugar acids, such as gluconic and xylonic acids, from glucose and xylose, respectively $[10,15,16]$. Characterization of the oleaginous profile of S. podzolica DSM 27192 showed, that the strain accumulates up to 31.8 and $27.53 \%$ lipid per dry biomass on glucose and xylose, respectively. A recent process optimisation revealed that both $\mathrm{pH}$ and temperature influence oil accumulation in S. podzolica DSM 27192 with $~ 40 \%$ increase in lipid productivity achieved under the optimised relative to the standard cultivation condition [10]. Despite these advances, including the improved sugar-uptake efficiency of $\sim 91$ and $92 \%$ for glucose and xylose, respectively, under fed-batch cultivation mode, the genetic basis of carbon flux partitioning between lipid and sugar acids syntheses remains unclear. In this work, we used an RNAseq strategy to elucidate the gene expression dynamics of the oleaginous yeast Saitozyma podzolica DSM 27192 cultivated on glucose and xylose.

\section{Materials and Methods}

\subsection{Yeast Strain and Experimental Set Up}

The oleaginous yeast Saitozyma podzolica DSM 27192 was isolated from peat bog soil in the Black Forest of Germany [15]. The yeast is maintained as glycerol stock in $-80^{\circ} \mathrm{C}$ storage and reactivated on YM agar as previously described [10].

Cultivation of the yeast was performed in duplicates in $2.5 \mathrm{~L}$ benchtop bioreactors (Infors HT, Bottmingen, Switzerland; Minifors fermentor) containing 1.2 L mineral salt medium as previously described [10]. Briefly, the cultivation parameters were $\mathrm{pH} 4,22.5^{\circ} \mathrm{C}$, $600 \mathrm{rpm}$ and $1 \mathrm{vvm}$ aeration rate for $144 \mathrm{~h}$ of process time. The first $48 \mathrm{~h}$ comprised a batch phase for biomass production. At the end of this phase, the concentration of glucose or xylose was $\sim 10 \mathrm{~g} / \mathrm{L}$ and the nitrogen (ammonia) concentration was nearly approaching zero. At $48 \mathrm{~h}$, a continuous automatic feed supply was established to maintain glucose or xylose concentration constant at $\sim 10 \mathrm{~g} / \mathrm{L}$ for lipid production during the rest of the cultivation. Yeast growth and production were tracked by daily sampling and analysis of dry cell mass, carbon source and ammonia consumption and lipid and organic acid content as described in [10].

Briefly, $1 \mathrm{~mL}$ sample from each time point was collected and used to determine the cell dry weight (CDW) as well as the sugar, organic acid and ammonium concentrations. The sample was centrifuged at 20,000 $\times g$ for $3 \mathrm{~min}$. The pellets were washed using physiological saline and then centrifuged at $20,000 \times g$ for $3 \mathrm{~min}$. CDW was determined by weighing the dried pellets $\left(48 \mathrm{~h}\right.$ at $\left.60^{\circ} \mathrm{C}\right)$ using a precision balance.

Glucose concentration was quantified by enzymatic assay using D-glucose test kit from R-Biopharm (Art. No. 10716251035, R-Biopharm AG, Darmstadt, Germany), according to the manufacturer's protocol.

Xylose and organic acid concentration were determined by analysing $10 \mu \mathrm{L}$ (injection volume) of the supernatant obtained above using HPLC (Agilent 1100 Series, Agilent Technologies Deutschland GmbH, Böblingen, Germany) equipped with a Rezex ROA 
organic acid $\mathrm{H}+(8 \%)$ guard column $(8 \mu \mathrm{m}, 50 \mathrm{~mm} \times 7.8 \mathrm{~mm})$ (Phenomenex Inc., Aschaffenburg, Germany) followed by a Rezex ROA organic acid H+ $(8 \%)$ column $(8 \mu \mathrm{m}$, $300 \mathrm{~mm} \times 7.8 \mathrm{~mm}$ ) (Art. No. 00H-0138-K0, Phenomenex Inc., Aschaffenburg, Germany) and a reversed-phase column Synergi ${ }^{\mathrm{TM}} 4 \mu \mathrm{m}$ Fusion-RP $80 \AA$ (150 mm $\left.\times 4.6 \mathrm{~mm}\right)$ (Art. No. 00F-4424-E0, Phenomenex Inc., Aschaffenburg, Germany) used for organic acid analytics.

For xylose, $50{ }^{\circ} \mathrm{C}$ column temperature, $5 \mathrm{mM} \mathrm{H}_{2} \mathrm{SO}_{4}$ mobile phase with $0.5 \mathrm{~mL} / \mathrm{min}$ flow rate were used, and the compound was detected using a refractive index detector (Agilent 1200 series, Agilent Technologies Deutschland GmbH, Böblingen, Germany). The supernatant was diluted with $20 \mathrm{mM} \mathrm{KH}_{2} \mathrm{PO}_{4} \mathrm{pH} 2.5$ prior to organic acids quantification. A gradient mobile phase comprising $20 \mathrm{mM} \mathrm{KH}_{2} \mathrm{PO}_{4} \mathrm{pH} 2.5$ and $100 \%$ methanol was used at $1 \mathrm{~mL} / \mathrm{min}$ to separate the compounds. The oven column was set at $30^{\circ} \mathrm{C}$ and the compounds were detected using a UV detector $(220 \mathrm{~nm})$.

Concentration of ammonium nitrogen was determined photometrically by modifying the assay volume to $300 \mu \mathrm{L}$ per sample in microtiter plates using the Spectroquant kit (1.14752.0001, Merck KGaA, Darmstadt, Germany).

Lipids were first derivatized to fatty acid methyl esters (FAMEs) by direct transesterification of yeast cell mass as described by $[15,17]$. Approximately $20-30 \mathrm{mg}$ freezedried cell mass was acid esterified using a two-phase system. The first phase comprised $0.5 \mathrm{~mL} 2 \mathrm{mg} / \mathrm{mL}$ heptadecanoic acid in hexane and $1.5 \mathrm{~mL}$ pure hexane. The second phase contained equal volumes of $2 \mathrm{~mL} 15 \% \mathrm{H}_{2} \mathrm{SO}_{4}$ in methanol. A thermo-shaker (Universal Labortechnik, Leipzig, Germany) was used to incubate the mixture at $100{ }^{\circ} \mathrm{C}$ and $1000 \mathrm{rpm}$ for $2 \mathrm{~h}$. Samples were vortexed at $30 \mathrm{~min}$ intervals, and the reaction was stopped by placing the reaction tubes on ice for $10 \mathrm{~min}$. The upper phase containing FAMEs was analysed by gas chromatography (GC) using the 6890N Network GC-System (Agilent Technologies Deutschland GmbH, Waldbronn, Germany) coupled with a DB-Wax column $(30 \mathrm{~m} \times 0.25 \mathrm{~mm})$ (Art. No. 122-7032; Agilent Technologies Deutschland GmbH, Böblingen, Germany). Sample separation was done by using a temperature gradient of $40-250{ }^{\circ} \mathrm{C}$ at $8{ }^{\circ} \mathrm{C} / \mathrm{min}$. Final temperature was maintained at $250^{\circ} \mathrm{C}$ for $10 \mathrm{~min}$ and the FAMEs were detected and quantified based on the RM3 FAME Mix standard (Art. No. 07256-1AMP, Sigma Aldrich, Taufkirchen, Germany).

\subsection{RNA Isolation, Library Construction and Sequencing}

To compare the transcriptome profiles of Saitozyma podzolica DSM 27192 under different carbon sources and over the course of the two growth phases, biomass was sampled at $22,46,70$ and $120 \mathrm{~h}$. The biomass was pelleted by centrifugation, snap-frozen with liquid nitrogen and stored at $-80^{\circ} \mathrm{C}$ until RNA extraction. Total RNA extraction and mRNA sequencing was performed at Microsynth AG (Balgach, Switzerland). Illumina-stranded TruSeq RNA libraries were prepared after poly(A) enrichment and sequenced based on Illumina NextSeq $(2 \times 150 \mathrm{bp}$ as paired-end) sequencing chemistry.

\subsection{RNA-Seq Data Analyses}

Raw reads were evaluated with FastQC v0.11.9 [18] and low-quality reads filtered using fastp v0.20.1 [19] with default parameters. High-quality reads were aligned against the Saitozyma podzolica DSM 27192 draft genome sequence [20] using HISAT2 v2.1.0 [21]. The samtools v1.2 [22] sorted BAM files we used to perform reference guided transcriptome assembly using StringTie v1.3.4d $[23,24]$ with ' $-\mathrm{e}$ ', and 'stringtie -merge' with '-m 300 c 0.5 -F 0.5 -f $0.05^{\prime}$ options. The resultant assembly was evaluated using gffcompare v0.10.6 [25]. To generate gene counts for differential gene expression analysis, we used prepDE.py (http:/ / ccb.jhu.edu/software/stringtie/dl/prepDE.py, accessed on 20 August 2020). Differential gene expression (DGE) analysis was performed using DESeq2 [26] implemented in iDEP v9.2 [27] with gene count filter of counts per million (CPM) $\geq 0.5$ in at least 2 libraries. The $\log 2$ fold change $(\log 2 \mathrm{FC})$ and false discovery rate thresholds were set at $<0.05$ and $>1.5$, respectively. The count data was transformed based on the DESeq2 [26] regularized logarithm transformation (rlog) method and principal component 
analysis (PCA) was computed and visualised using iDEP v9.2 [27]. Time course DGE analysis was performed using maSigPro package $[28,29]$ in R v4.0.2 with default settings except number of cluster $\mathrm{k}$ set at 6 and $R^{2}$ threshold of $\geq 0.7$.

\subsection{Functional Analysis of Expressed Genes}

Stringtie assembled transcripts were processed further using TransDecoder v5.5.0 (https:/ / github.com/TransDecoder/TransDecoder, accessed on 20 August 2020) to obtain putative protein sequences. The candidate protein sequences obtained with TransDecoder were subsequently compared with predicted proteins from the Saitozyma podzolica DSM 27192 draft genome sequence with the aid of cd-hit v4.8.1 [30] to compile a complete set of full-length protein sequences for all expressed genes. The protein sequences were annotated using pannzer2 [31], KofamKOALA [32], eggNOG [33] and InterProScan v5 [34], respectively. The functional enrichment analysis reported here is primarily based on gene ontology (GO) annotation, unless otherwise stated. To evaluate the functional implication of differential gene expression, we performed GO term enrichment analyses using WebGestalt 0.4.4 with default setting and to reduce GO term redundancy, affinity propagation based on apcluster was applied [35].

\subsection{Phylogenetic Analysis of Sugar Transport Proteins}

The predicted protein sequences associated with overexpressed sugar transporters were further annotated using BLASTp against the conserved domain database [36], the curated UniProtKB/Swiss-Prot [37] and transporter classification [38] databases as well as prediction of transmembrane helices using TMHMM Server v2.0 [39]. The proteins were aligned using PSI/TM-Coffee [40] with UniRef100 homology extension and transmembrane sequence type options. A phylogenetic tree was constructed using IQ-TREE v1.6.11 [41].

\section{Results and Discussion}

\subsection{Overview of Yeast Cultivation and RNA-Seq}

The oleaginous yeast Saitozyma podzolica DSM 27192, cultivated on glucose and xylose (Figure 1) was sampled for RNA-sequencing (RNA-seq) at 22, 48, 70 and $120 \mathrm{~h}$ with a view to evaluate the transcriptional response of the yeast during growth on the two sugars. For this study, we partitioned the cultivation into two stages. During the initial batch phase ( $\sim-48 \mathrm{~h}$ ) on glucose (Figure 1a), the yeast grew to a maximum cell mass of $14.03 \pm 1.31 \mathrm{~g} / \mathrm{L}$ at $48 \mathrm{~h}$. At this time point, $\sim 91.44 \%$ of ammonium was metabolised by the yeast. Cultivation of the yeast under batch mode on xylose followed the trend observed with glucose (Figure $1 \mathrm{~b}$ ). After $48 \mathrm{~h}$ growth on xylose, the yeast attains a maximum cell mass of $11.00 \pm 0.85 \mathrm{~g} / \mathrm{L}$ and metabolised $\sim 80.65 \%$ of the nitrogen source. The second phase ( 48-144 h) involved establishment of a continuous feeding at $\sim 10 \mathrm{~g} / \mathrm{L}$ sugars concentration under nitrogen limitation as previously described [10]. In both glucose and xylose cultures, ammonium was metabolised completely around $70 \mathrm{~h}$ (Figure $1 \mathrm{a}, \mathrm{b}$ ). The biomass increased steadily to a maximum of $26.78 \pm 3.50$ (Figure 1a) and $25.38 \pm 0.25 \mathrm{~g} / \mathrm{L}$ (Figure $1 \mathrm{~b}$ ) on glucose and xylose, respectively. The latter phase is characterised by accumulation of singlecell oil (SCO), a process triggered by nitrogen limitation, with the complete depletion of the nitrogen source at $70 \mathrm{~h}$ [9]. For instance, compared to sampling time point $46 \mathrm{~h}$, lipid accumulation, estimated based on percent FAME per cell dry weight, increased by 132 and $126 \%$ at $90 \mathrm{~h}$ and by $\sim 209$ and $195 \%$ at $144 \mathrm{~h}$ for glucose and xylose cultures, respectively [9].

Four RNA samples, one from the batch phase and three from the fed-batch phases, have been sequenced using NextSeq $2 \times 150$ (v2.5) sequencing chemistry. After trimming out sequencing adapters and filtering out low-quality reads, the data comprised $\sim 1.5$ billion high-quality and clean reads of $\sim 224 \mathrm{~Gb}$ (Figure 2a). The glucose dataset comprised a range of $\sim 32.7-62.6$ million reads of size ranging between $\sim 4.8$ and $\sim 9.2 \mathrm{~Gb}$ and for xylose the dataset consisted of $\sim 38.6-61.9$ million reads ranging between $\sim 5.6$ and $\sim 9.0 \mathrm{~Gb}$ in size. Initial reads alignment using Hisat2 against the draft genome of S. podzolica DSM 27192 [20] resulted in an average read alignment rate of $95.05 \%$ with a range of $\sim 89.47-97.19 \%$ 
(Figure $2 b$ ), signifying the quality and the accuracy of the sequencing data. StringTie assembly evaluation using GffCompare [25] revealed 10,670 super-loci, including 2039 (19.1\%) novel loci, which represent transcripts that are missing or novel isoforms of genes in the previous annotation of S. podzolica DSM 27192.
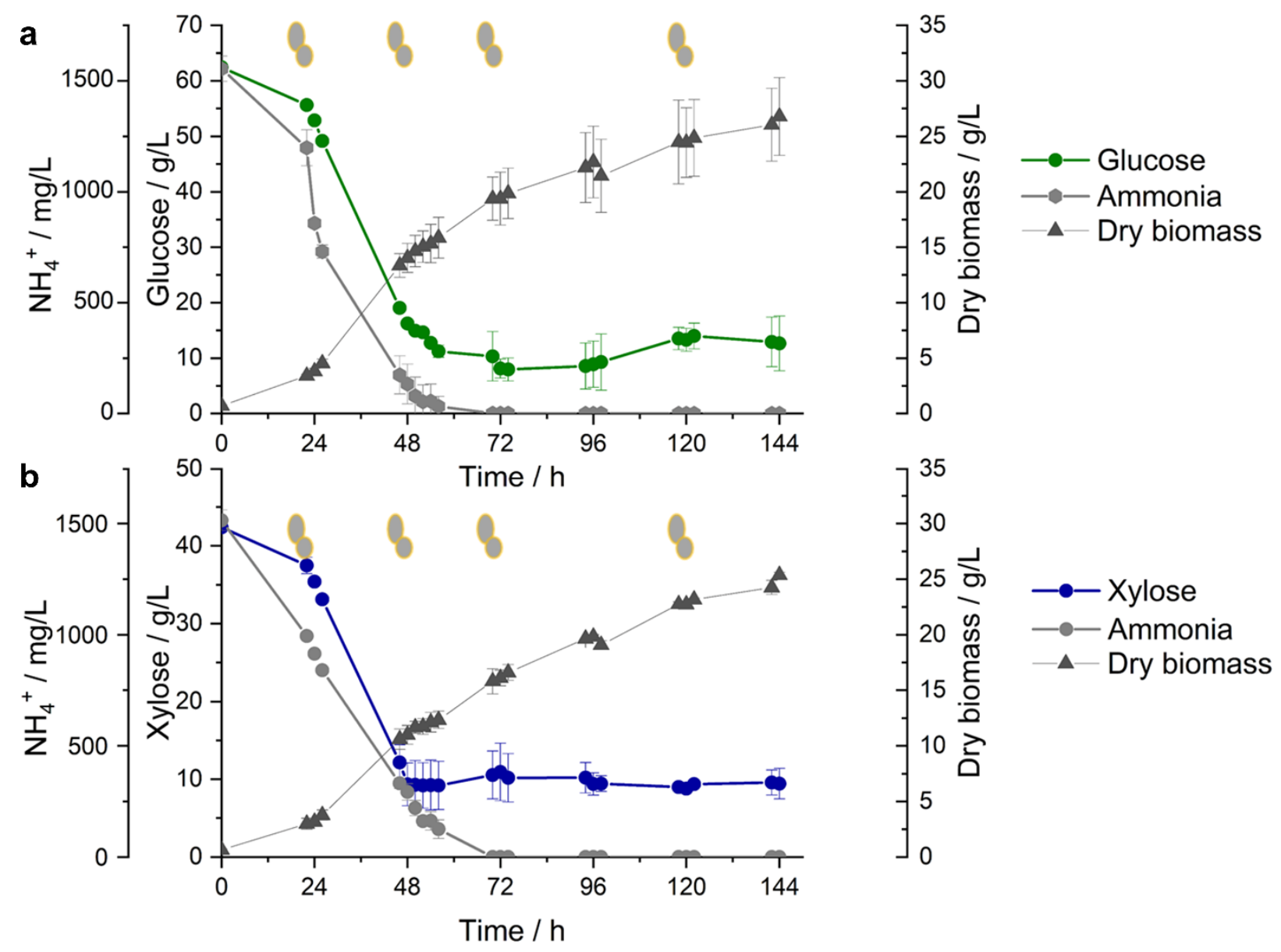

Figure 1. Overview of Saitozyma podzolica DSM 27192 cultivation on (a) glucose and (b) xylose. A batch-fed process was established at $\sim 48 \mathrm{~h}$ for both sugars under nitrogen limitation. Grey cells indicate sampling points at which the yeast was harvested for RNA sequencing and subsequent analyses.

To improve the downstream gene expression analysis, we removed genes with inconsistent expression by implementing a stringent filter (minimum counts per million $(\mathrm{CPM}) \geq 0.5$ in a minimum of 2 libraries), resulting in 10,506 genes with various expression profiles across the samples. The distribution of normalised gene counts based on the regularized logarithm transformation (rlog) implemented in DESeq2 [26] is presented in Figure 2c,d. Clustering of the samples, using principal component analysis (PCA), showed that biological replicates for each sampling point cluster distinctly from samples of other time points. Interestingly, samples from 22 and $46 \mathrm{~h}$ sampling points cluster more closely together for both glucose and xylose grown yeast compared to those from 70 and $120 \mathrm{~h}$ samples, suggesting greater variability between the former and the latter sets. However, the first two principal components explained only $59 \%$ of the observed variability, suggesting that differences exist among transcriptome profiles of S. podzolica DSM 27192 growing on glucose and xylose, and across the four sampling time points. 

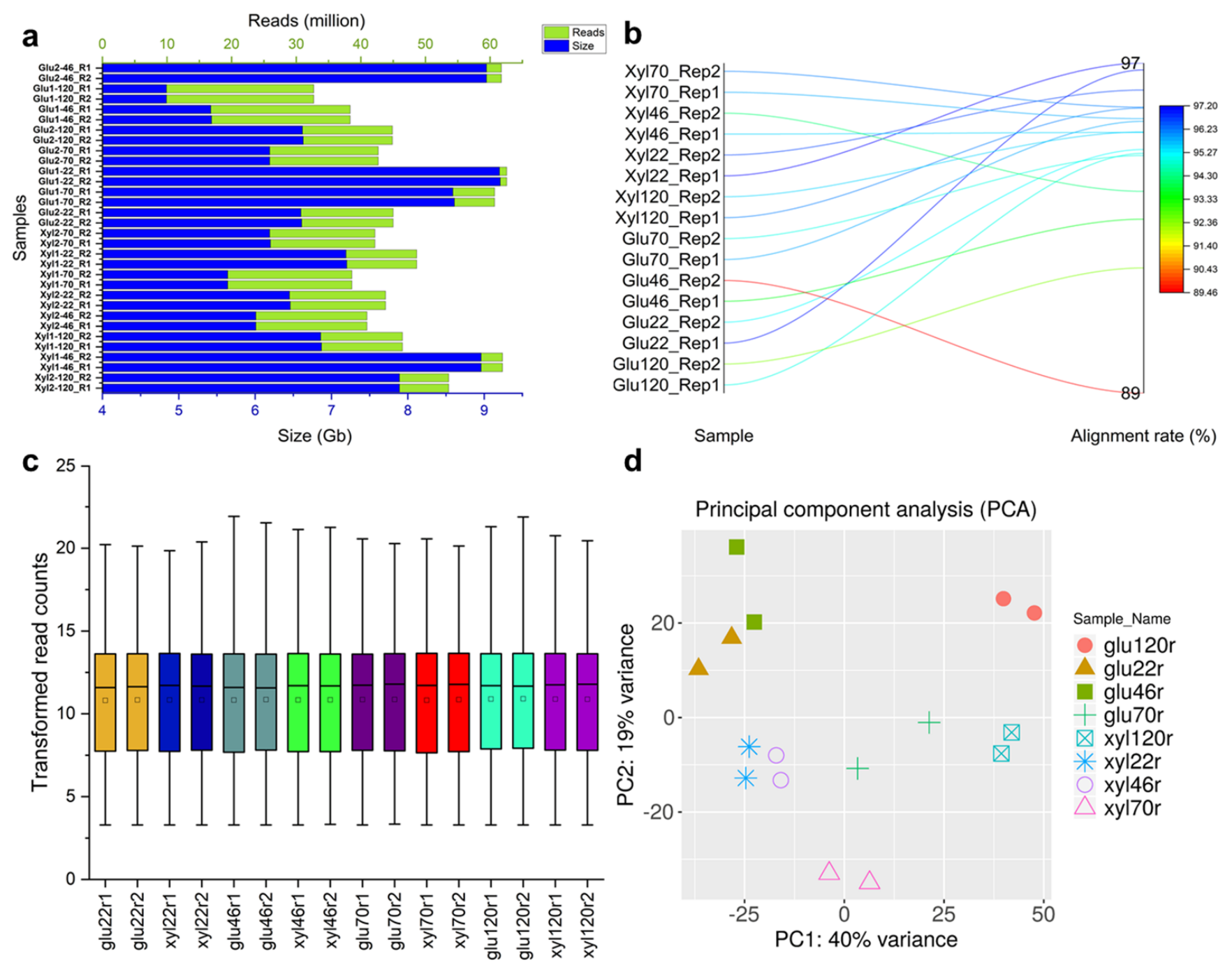

Figure 2. Quality metrics of RNA-sequencing reads of Saitozyma podzolica DSM 27192 cultivated on glucose and xylose. (a) Read count and sizes per library from all samples, including both strands of each read pair. (b) Overall alignment rate (\%) on the draft genome of S. podzolica DSM 27192. (c) Boxplot of normalised and transformed read counts. (d) Principal component analysis plot showing variance among samples and between biological replicates.

\subsection{Differential Gene Expression during Initial Growth under Glucose and Xylose in DSM 27192}

To investigate possible genetic differences and genes shaping initial growth of Saitozyma podzolica DSM 27192 on glucose and xylose, we compared gene expression profiles of the $22 \mathrm{~h}$ samples using DESeq2 [26]. There were 361 differentially expressed (FDR $<0.05$, and $\log 2 \mathrm{FC}>1.5$; Figure S1a) genes (representing $~ 3.4 \%$ of the expressed genes) observed when the yeast was grown on glucose compared to xylose. Further evaluation of the expression profiles revealed upregulation of 115 and down-regulation of 246 genes during growth on glucose relative to xylose (Figure $\mathrm{S} 1 \mathrm{~b}$ ).

To gain insight into signatures of molecular activities associated with initial growth of the yeast on glucose and xylose, we performed gene ontology (GO)-based functional enrichment analysis using WebGestalt [35]. Interestingly, various GO associated with transmembrane transport is associated with the observed overexpressed genes. For instance, overrepresentation of transmembrane transport (GO:0055085; FDR $=0.07)$, including at least six of the 15 genes annotated as sugar (and other) transporter genes, was observed during initial growth on glucose relative to xylose (Table 1 and Table S1). By contrast, a more diverse set of genes associated with the transmembrane transporter activity of GO:0022857 was significantly overrepresented (FDR < 0.05) among upregulated genes 
during growth on xylose compared to glucose (Table 1 and Table S1). As with glucose upregulated genes, the majority of these ( 23 out of 51 genes) have been annotated as a sugar (and other) transporter gene (Table S1). Besides the predominance of these, genes of $\mathrm{K}^{+}$transporter proteins in the glucose grown yeast, formate nitrite transporter, fungal trichothecene efflux pump, mitochondrial carrier, voltage-gated $\mathrm{K}$ channel and other general substrate transporter proteins in xylose grown cultures, were linked to the overrepresented transmembrane transport function (Table S1), suggesting a significant variation in the movement of the two sugars in Saitozyma podzolica DSM 27192. Overrepresentation of transmembrane transporter GOs, which indicates active transmembrane transport of a variety of substrates has been reported in many fungi [42,43]. Unlike the observed significant and specific enrichment of these GOs in glucose and xylose grown yeast observed in this study, genes associated with both GOs (GO:0022857 and GO:0055085) were reported to be up and downregulated on glucose grown Aspergillus fumigatus mutants [44].

Table 1. Functional enrichment of differentially expressed genes (at $22 \mathrm{~h}$ time point) of Saitozyma podzolica DSM 27192 growing on glucose compared to xylose based on WebGestalt. BP and MF indicate biological process and molecular function, respectively. DE and FDR represent differential expression and false discovery rate, respectively.

\begin{tabular}{|c|c|c|c|c|c|c|c|c|c|}
\hline DE & Category & GO & Ontology Definition & Size & Overlap & Expect & Ratio & $p$-Value & FDR \\
\hline \multirow[t]{3}{*}{ Up } & $\mathrm{BP}$ & GO:0055085 & \multirow{3}{*}{$\begin{array}{c}\text { transmembrane transport } \\
\text { transmembrane transporter } \\
\text { activity } \\
\text { transporter activity }\end{array}$} & 725 & 15 & 5.08 & 2.95 & $4.4 \times 10^{-5}$ & $7.1 \times 10^{-2}$ \\
\hline & MF & GO:0022857 & & 650 & 14 & 4.55 & 3.07 & $5.8 \times 10^{-5}$ & $7.1 \times 10^{-2}$ \\
\hline & MF & GO:0005215 & & 660 & 14 & 4.62 & 3.03 & $6.9 \times 10^{-5}$ & $7.1 \times 10^{-2}$ \\
\hline \multirow[t]{9}{*}{ Down } & MF & GO:0022857 & $\begin{array}{l}\text { transmembrane transporter } \\
\text { activity }\end{array}$ & 650 & 51 & 20.69 & 2.46 & $1.8 \times 10^{-10}$ & $4.7 \times 10^{-7}$ \\
\hline & MF & GO:0005215 & \multirow{4}{*}{$\begin{array}{l}\text { transporter activity } \\
\text { hydrolase activity, hydrolyzing } \\
\text { O-glycosyl compounds } \\
\text { transmembrane transport } \\
\text { hydrolase activity, acting on } \\
\text { glycosyl bonds }\end{array}$} & 660 & 51 & 21.01 & 2.43 & $3.1 \times 10^{-10}$ & $4.7 \times 10^{-7}$ \\
\hline & MF & GO:0004553 & & 171 & 24 & 5.44 & 4.41 & $4.5 \times 10^{-10}$ & $4.7 \times 10^{-7}$ \\
\hline & BP & GO:0055085 & & 725 & 53 & 23.08 & 2.30 & $9.7 \times 10^{-10}$ & $7.5 \times 10^{-7}$ \\
\hline & MF & GO:0016798 & & 184 & 24 & 5.86 & 4.10 & $2.1 \times 10^{-9}$ & $1.3 \times 10^{-6}$ \\
\hline & BP & GO:0005975 & \multirow{4}{*}{$\begin{array}{l}\text { carbohydrate metabolic process } \\
\text { carbohydrate catabolic process } \\
\text { polysaccharide catabolic process } \\
\text { metallocarboxypeptidase } \\
\text { activity }\end{array}$} & 357 & 33 & 11.36 & 2.90 & $1.3 \times 10^{-8}$ & $6.7 \times 10^{-6}$ \\
\hline & BP & GO:0016052 & & 89 & 11 & 2.83 & 3.88 & $1.0 \times 10^{-4}$ & $4.5 \times 10^{-2}$ \\
\hline & $\mathrm{BP}$ & GO:0000272 & & 37 & 7 & 1.18 & 5.94 & $1.3 \times 10^{-4}$ & $5.2 \times 10^{-2}$ \\
\hline & MF & GO:0004181 & & 10 & 4 & 0.32 & 12.57 & $1.8 \times 10^{-4}$ & $6.1 \times 10^{-2}$ \\
\hline
\end{tabular}

\subsection{Distinct Profiles of Putative Sugar Transporter Genes in Saitozyma Podzolica DSM 27192 Grown on Glucose and Xylose}

To evaluate the potential implication of variation in the above differentially expressed sugar (and other) transporter genes during growth of the oleaginous yeast on xylose and glucose, we performed additional annotation of the predicted proteins using conserved domain database [36], the curated UniProtKB/Swiss-Prot [37] and transporter classification [38] databases as well as prediction of transmembrane helices using TMHMM Server v2.0 [39]. The analysis showed that the predicted proteins of 42 of the 65 differentially expressed transmembrane transport-associated genes under glucose and xylose (Table S1) shared significant homology (e-value, and a bit score range of $1.0 \times 10^{-13}-5.0 \times 10^{-220}$ and 75.1-761, respectively) with members of sugar porter family: 2.A.1.1. However, these proteins shared low homology with the sugar porter proteins, and the curated yeast transporters, with similarity values ranging between $23.3-72.5 \%$, respectively, suggesting novelty of the putative transporters in S. podzolica DSM 27192 when compared to their closest characterised relatives.

Phylogeny-based evaluation of proteins of the above sugar porter genes showed a clustering of the 7 and 35 putative sugar (and others) transporters significantly overexpressed in glucose and xylose, respectively, in six groups. (Figure 3). Cluster 1 harbours the majority of the functionally characterised sugar transporters included in this analysis and includes 2 and 11 putative transporters whose genes were significantly overexpressed in glucose and xylose, respectively. However, within this cluster, distinct transporter pro- 
teins whose genes were significantly upregulated $\left(\log 2 \mathrm{FC}=2.0\right.$ and $\left.\mathrm{FDR}=4.0 \times 10^{-2}\right)$ in glucose (EHS25_008238) and xylose (EHS25_001351; $\log 2 \mathrm{FC}=1.4$ and FDR $=1.2 \times 10^{-2}$ ) cluster with glycerol: $\mathrm{H}^{+}$symporters of families 2.A.1.1.125 and 2.A.1.1.38, respectively. Orthologue of 2.A.1.1.125, characterised in Schizosaccharomyces pombe was shown to share regions of transmembrane domain with several other transmembrane transporters, including those of xylose, glucose and glycerol [45] and showed varied expression depending on available substrate [46], indicating that the overexpressed gene in S. podzolica is likely a glucose transporter. By contrast, the gene of STL1 (2.A.1.1.38) was reported to be repressed alongside glycerol transport by glucose in Saccharomyces cerevisiae [47]. However, the low homology (30.3\% similarity value) shared between EHS25_001351 and homologues of STL1 suggest that the former is a putative xylose rather than glycerol transporter but similarly repressed by glucose in S. podzolica. This is further supported by the presence, within the same cluster, of one xylose facilitator of family 2.A.1.1.40 [48] which grouped closely with the xylose overexpressed $\left(\log 2 \mathrm{FC}=2.90\right.$ and FDR $\left.=1.4 \times 10^{-13}\right)$ EHS25_002168, sharing $39 \%$ identity. In S. cerevisiae, homologues of STL1 and xylose transporters share similarity values $\leq 27 \%$ [47].

The second subcluster includes glucose overexpressed $(\log 2 \mathrm{FC}=1.2$ and FDR $=1.0 \times 10^{-8}$ ) protein (EHS25_004977) distinctly clustering with families of high affinity glucose transporters of 2.A.1.1.57, low affinity glucose transporters (2.A.1.1.108) and low affinity glucose: $\mathrm{H}^{+}$symporter along with one xylose overexpressed $(\log 2 \mathrm{FC}=1.9$ and FDR $=7.6 \times 10^{-18}$ ) protein (EHS25_002417) while two proteins, EHS25_006731 $\left(\log 2 \mathrm{FC}=4.7\right.$ and FDR $\left.=5.1 \times 10^{-35}\right)$ and EHS25_007017 $(\log 2 \mathrm{FC}=3.6$ and FDR $=8.7$ $\times 10^{-14}$ ), upregulated in xylose clusters with families 2.A.1.1.57 and 2.A.1.1.64. The former includes several high affinity glucose and other monosaccharide, including xylose symporters while the latter is a family of hexose sensors $[49,50]$. Some of the xylose induced transporters also affiliate to the more general or broad sugar transporters such as sugar and polyol transporter 1 (2.A.1.1.69) and probable metabolite transport protein (2.A.1.1.96). Interestingly, this subcluster contains putative sugar transporter genes with the highest expression level in xylose relative to glucose grown S. podzolica. These include EHS25_007263 $\left(\log 2 \mathrm{FC}=9.86\right.$ and FDR $\left.=2.1 \times 10^{-4}\right)$ and EHS25_009861 $(\log 2 \mathrm{FC}=9.34$ and $1.6 \times 10^{-3}$, Table S1) which are closely affiliated with families 2.A.1.1.69 (above) and 2.A.1.1.8 (myoinositol:H+ symporter) in the sugar (and others) transporter phylogeny.

The second major clade (Figure 3), which includes two proteins of genes, EHS25_000002 $\left(\log 2 \mathrm{FC}=1.4\right.$ and $\left.\mathrm{FDR}=2.7 \times 10^{-3}\right)$ and EHS25_005912 $(\log 2 \mathrm{FC}=2.3$ and FDR $\left.=1.1 \times 10^{-6}\right)$, upregulated in glucose and 12 proteins of xylose upregulated genes cluster distantly with proteins from two families, general $\alpha$-glucoside: $\mathrm{H}^{+}$symporter (2.A.1.1.11) and maltose permease (2.A.1.1.138). Combined, these proteins shared a range $\%$ identity of $23.3-35.5 \%$, supporting their distinctiveness from the maltose transporters. Furthermore, genes coding proteins of both 2.A.1.1.11 and 2.A.1.1.138 have been reported to be repressed by glucose in Saccharomyces pastorianus and Hansenula polymorpha, respectively [51,52]. Cluster 2 harbours putative sugar transporter genes showing the highest expression levels among the analysed sugar (and others) transporter under xylose relative to glucose (Table S1). For instance, EHS25_000641, EHS25_001049, EHS25_001332, and EHS25_008491 were significantly up-regulated (FDR $<0.05)$ with $\log 2 \mathrm{FC}$ values ranging between 9.07 and 12.69 (Table S1).

Cluster 3 also includes two putative sugar transporter genes EHS25_000057 and EHS25_009483, which were highly induced under xylose relative to glucose with log2FC values of 11.59 and 10.26 (Table S1). The proteins of these significantly overexpressed (FDR < 0.05) putative sugar transporter genes, however, grouped with a cellobiose/ cellotriose/cellodextrin/lactose transporter (2.A.1.1.83; Figure 3) but as with the predicted proteins described in clusters 1 and 2, shared low similarity values ranging between 34.4 and 41.5 with the closest characterised protein of the family 2.A.1.1.83 [53], thereby suggesting a different role for the S. podzolica orthologues of this family. 


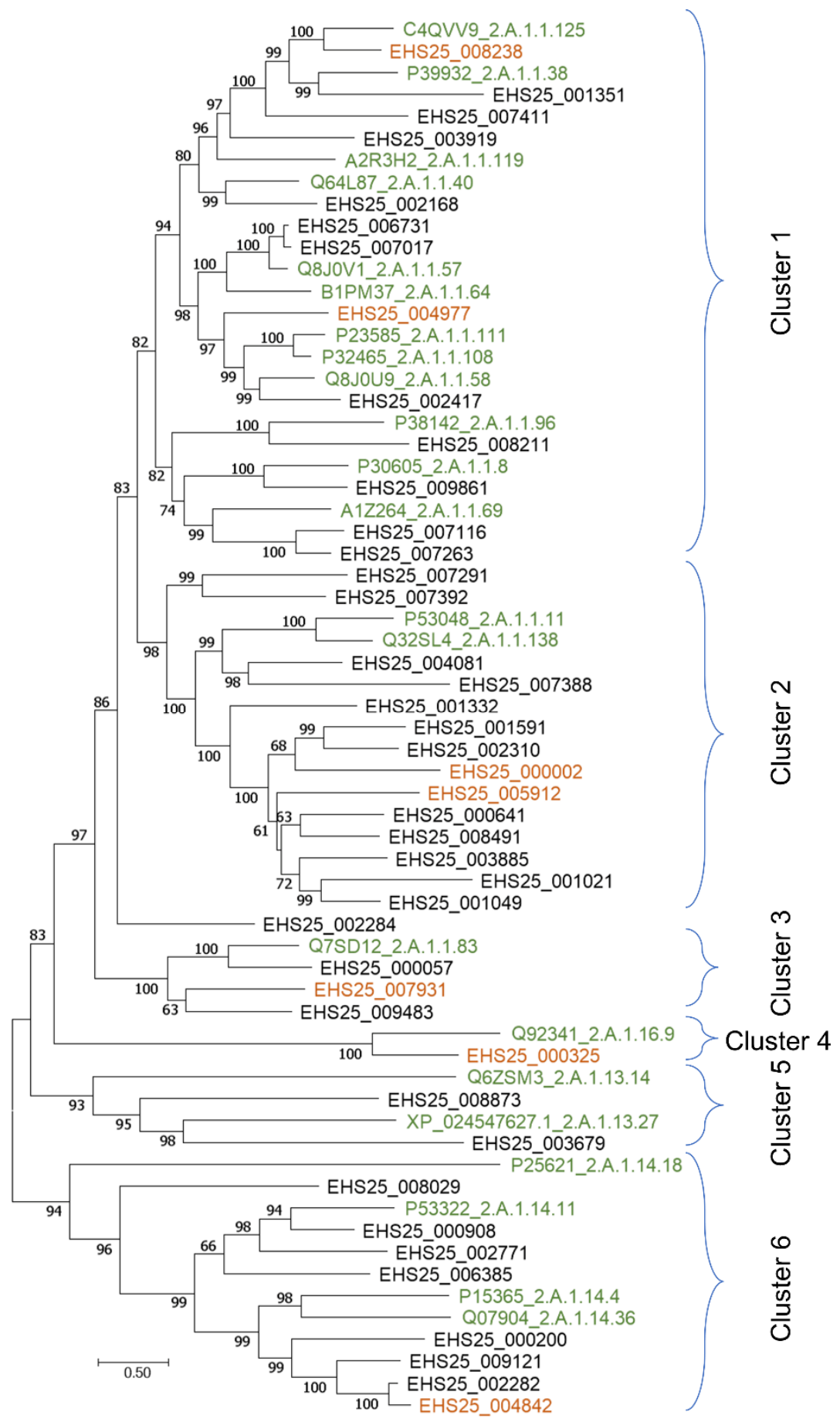

Figure 3. Maximum likelihood phylogeny of sugar (other) transport proteins predicted from overexpressed genes in Saitozyma podzolica DSM 27192 during initial growth $(22 \mathrm{~h}$ time point) on glucose and xylose. The tree was generated using the trimmed alignment (364 amino acids) of 64 protein sequences, including 22 closest references from TCDB based on LG + F+ R6 model with -bb 1000 using IQ-TREE v1.6.11. Orange and black fonts indicate overrepresented proteins (translated genes) in glucose and xylose, respectively, while green fonts represent top matching proteins from the transporter classification database. The alignment was generated using transmembrane proteins (PSI/TM-Coffee) function of T-Coffee.

Aside from the above three clusters, which contain putative sugar transporters, highly induced in the presence of glucose or xylose the rest of sugar (and other) proteins were 
grouped in clusters 4, 5 and 6 (Figure 3). Cluster 4 include a single $S$. podzolica protein with a significantly overexpressed $(\mathrm{FDR}<0.05)$ gene under glucose relative to xylose and affiliated siderophore iron transporter 3, Str3 (2.A.1.16.9) in the phylogeny (Figure 3). By contrast, cluster 5 comprises two proteins whose genes were overexpressed (FDR < 0.05 ) under xylose relative to glucose with the proteins being the most similar MFS transporter MFSG; family 2.A.1.13.27. Str3 participates in iron homeostasis in Schizosaccharomyces pombe and MFSG was associated with tolerance against glucosinolates $S$. cerevisiae [54].

Cluster 6 represents the third largest cluster, comprising proteins of 7 xylose and a single glucose-induced gene (Table S1). S. podzolica DSM 27192 proteins included in this cluster grouped distinctly with the anion:cation symporter (2.A.1.14) family of characterised transporters associated with various substrates including monocarboxylic acids (2.A.1.13.14), dipeptides (2.A.1.14.4) and thiamine pathway THI73 (2.A.1.14.36; Figure 3).

Combined, evidence from phylogeny, sequence homology and gene expression levels strongly suggest a putative sugar transport role for proteins included in cluster 1, 2 and 3 . The cache of putative sugar transporters in S. podzolica DSM 27192 could be used, therefore, to enhance production of useful bioproducts from a wide range of biomass hydrolysates. However, fermentation experiments with the closely related oleaginous yeast $C$. curvatus, and other oleaginous yeasts, revealed a repression of the consumption of xylose and other sugars by glucose $[51,52,55]$ and a decrease in consumption of both glucose and xylose by other components of biomass hydrolysate [56]. The ability of our yeast to utilize a mixture of sugars or to grow directly on the hydrolysates is still under consideration. Future characterisation of the putative S. podzolica sugar transporter proteins is, however, necessary to validate the predicted roles and the precise mechanisms associated with the predicted function.

3.4. Comparison of Transcriptome Profiles of Saitozyma Podzolica DSM 27192 during Continuous Feeding on Glucose and Xylose

To gain insight into the gene expression dynamics during the second phase of the cultivation (fed-batch) of S. podzolica DSM 27192 under glucose and xylose, two sets of comparison were performed (Figure 4). First, a comparison of the expression profiles for growth under glucose and xylose at $46 \mathrm{~h}, 70 \mathrm{~h}$ and $120 \mathrm{~h}$, was performed. A total of 2364 genes were differentially expressed (FDR $<0.05$, and $\log 2 \mathrm{FC}>1.5$ ) in glucose relative to xylose, over the period of the cultivation (Figure 4a). Of these, only 119 genes were common to all time points for the respective contrast between glucose and xylose profiles. The highest number (1292) of differentially expressed genes (DGEs), which includes 541 and 751 up and down regulated genes, respectively, was observed at the onset of the fed batch process (Figure $4 b$ ).

As with the expression profile from the batch cultivation and consistent with continued addition of sugars during this phase of growth, both the upregulated and downregulated genes at time point $46 \mathrm{~h}$ were significantly associated (FDR $<0.05$ ) with transmembrane activity (Table 2 and Table S2). By contrast, similar numbers of DEGs were observed at time points 70 and $120 \mathrm{~h}$ (Figure $4 \mathrm{a}, \mathrm{b}$ ). Consistently, hydrolase activity, hydrolysing O-glycosyl compounds (GO:0004553) was downregulated across the three time points in cultures grown with glucose relative to xylose (Table 2 and Table S2) as observed under batch cultivation (Table 1). Xylose induction of carbohydrate-active enzymes as well as repression of carbon catabolite by both glucose and xylose have been reported in different fungi [57-59]. For instance, cellulases and xylanases have been induced using xylose in Thermoascus aurantiacus [60]. Overexpression of these genes, therefore, suggests that xylose grown S. podzolica could be utilized or improved for an enhanced production of these enzymes. 


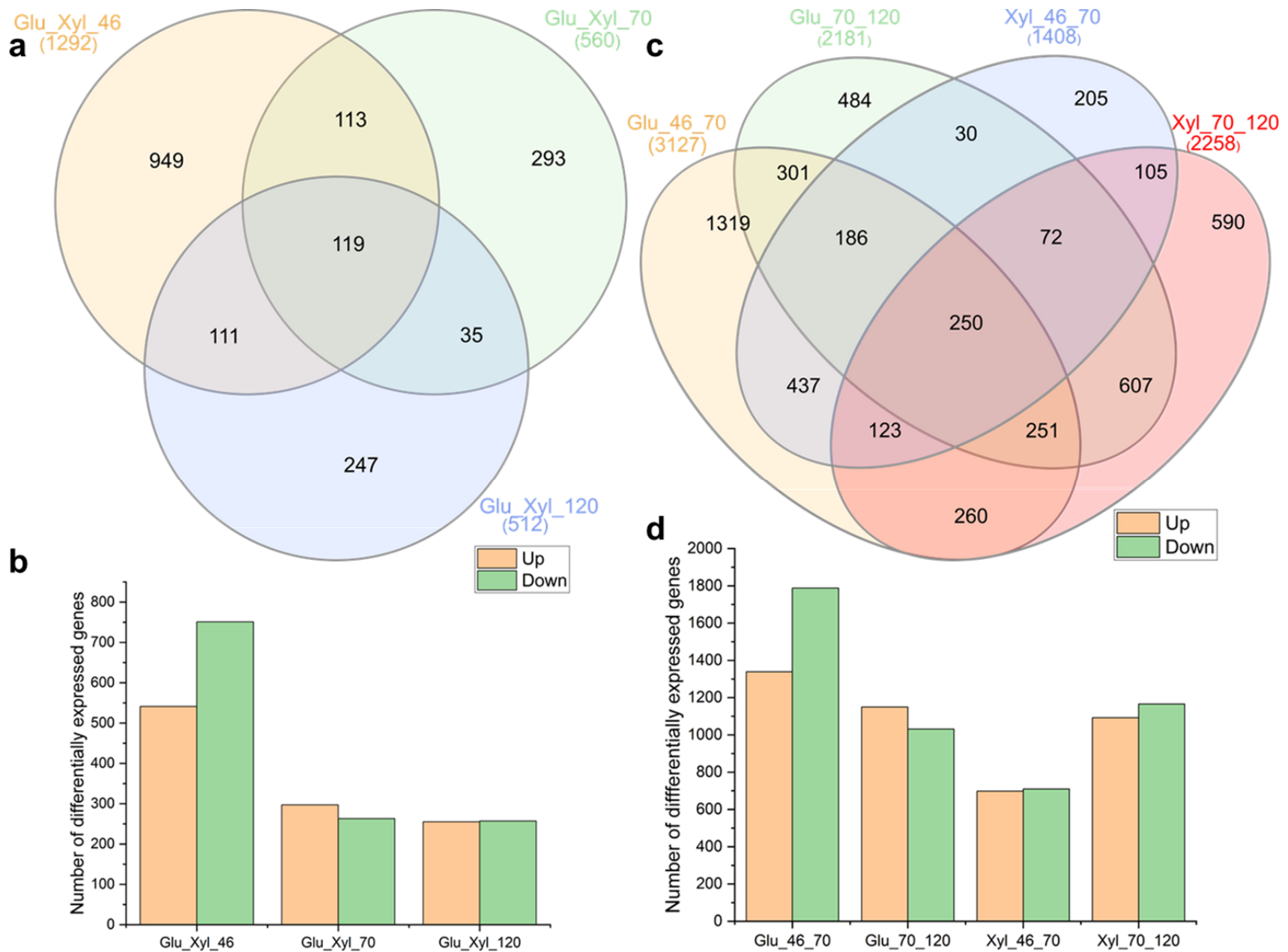

Figure 4. Differential gene expression (DGE) in Saitozyma podzolica DSM 27192 during fed batch cultivation on glucose and xylose. (a) Overlapping DGE for comparison between glucose and xylose grown cultures, (b) Number of up and down regulated genes in xylose grown cultures relative to glucose, (c) Overlapping DGE across the three time points in glucose and xylose grown cultures and (d) Number of up and downregulated genes across the three time points in glucose and xylose grown cultures.

Aside from these, two genes of $\mathrm{NAD}^{+}$-dependent formate dehydrogenase EHS25_002775 (FDR $=0.01$ and $\log 2 \mathrm{FC}-3.01)$ and EHS25_003099 (FDR $=0.02$ and $\log 2 \mathrm{FC}-1.78)$ were significantly downregulated in glucose relative to xylose grown cultures at $46 \mathrm{~h}$ (Table S2). Formate dehydrogenase oxidises formate to $\mathrm{CO}_{2}$ and the NADH generated from the reaction may serve as a source of reducing equivalents [61,62]. Formate dehydrogenase activity has been reported in S. cerevisiae and Candida tropicalis grown on glucose and xylose, respectively, as well as in a combination of these sugars with formate $[61,62]$. Two possible sources of formate during fermentation of glucose or xylose in S. podzolica are either exogenous formate in the culture medium or formate produced via NAD/NADP-NADH/NADPH interconversion and other pathways [63], with the latter source being more likely. Downregulation of formate dehydrogenase genes, EHS25_002530 $\left(\log 2 \mathrm{FC}=-4.79\right.$ and FDR $\left.=2.33 \times 10^{-3}\right)$, EHS25_002775 $(\log 2 \mathrm{FC}=-3.92$ and FDR $\left.=1.7 \times 10^{-6}\right)$ and EHS25_003099 $\left(\log 2 \mathrm{FC}=-3.28\right.$ and FDR $\left.=9.19 \times 10^{-11}\right)$ at 46 relative to $70 \mathrm{~h}$ sampling point and upregulation of EHS25_003099 $(\log 2 \mathrm{FC}=1.33$ and $\mathrm{FDR}=2.04 \times 10^{-2}$ ) at 70 relative to $120 \mathrm{~h}$ sampling point were also observed in culture growing under glucose (Table S2), suggesting significant formate dehydrogenase activity in glucose grown S. podzolica. Further evaluation of data revealed a significant upregulation of 3,4-dihydroxy-2-butanone 4-phosphate synthase gene (EHS25_006321; $\log 2 \mathrm{FC}=0.72$ and $\mathrm{FDR}=4.07 \times 10^{-2}$ ) at 46 relative to $70 \mathrm{~h}$ in glucose grown cultures (Table S2), suggesting 
a greater production of formate in glucose grown S. podzolica. 3,4-dihydroxy-2-butanone 4-phosphate synthase is a key enzyme of flavin biosynthesis catalysing the conversion of Dribulose 5-phosphate to 1-deoxy-L-glycero-tetrulose 4-phosphate by releasing formate [64].

Table 2. Functional enrichment of differentially expressed genes in Saitozyma podzolica DSM 27192 grown on glucose compared to xylose during fed batch cultivation based on WebGestalt. BP, CC and MF represent biological process, cellecular component and molecular function, respectively. DE and FDR represent differential expression and false discovery rate, respectively.

\begin{tabular}{|c|c|c|c|c|c|c|c|c|c|c|}
\hline Comparison & DE & Function & GO & Definition & Size & Overlap & Expect & Ratio & $p$-Value & FDR \\
\hline \multirow[t]{5}{*}{ Glu-Xyl-46 } & \multirow[t]{2}{*}{ Up } & MF & GO:0022857 & $\begin{array}{l}\text { transmembrane transporter } \\
\text { activity }\end{array}$ & 685 & 50 & 26.07 & 1.92 & $2.1 \times 10^{-6}$ & $5.0 \times 10^{-3}$ \\
\hline & & MF & GO:0046915 & $\begin{array}{c}\text { transition metal ion } \\
\text { transmembrane transporter } \\
\text { activity }\end{array}$ & 21 & 7 & 0.80 & 8.76 & $7.7 \times 10^{-6}$ & $7.0 \times 10^{-3}$ \\
\hline & \multirow[t]{3}{*}{ Down } & MF & GO:0004553 & $\begin{array}{l}\text { hydrolase activity, hydrolyzing } \\
\text { O-glycosyl compounds }\end{array}$ & 179 & 40 & 13.21 & 3.03 & $8.2 \times 10^{-11}$ & $2.6 \times 10^{-7}$ \\
\hline & & MF & GO:0022857 & $\begin{array}{c}\text { transmembrane transporter } \\
\text { activity }\end{array}$ & 685 & 87 & 50.53 & 1.72 & $7.1 \times 10^{-8}$ & $4.4 \times 10^{-5}$ \\
\hline & & $\mathrm{BP}$ & GO:0045333 & cellular respiration & 48 & 13 & 3.54 & 3.67 & $2.8 \times 10^{-5}$ & $7.4 \times 10^{-3}$ \\
\hline \multirow[t]{3}{*}{ Glu-Xyl-70 } & \multirow[t]{3}{*}{ Down } & MF & GO:0004553 & $\begin{array}{c}\text { hydrolase activity, hydrolyzing } \\
\text { O-glycosyl compounds }\end{array}$ & 179 & 28 & 4.65 & 6.03 & $4.0 \times 10^{-15}$ & $1.2 \times 10^{-11}$ \\
\hline & & $\mathrm{BP}$ & GO:0010383 & $\begin{array}{c}\text { cell wall polysaccharide metabolic } \\
\text { process }\end{array}$ & 26 & 6 & 0.67 & 8.89 & $4.1 \times 10^{-5}$ & $2.6 \times 10^{-2}$ \\
\hline & & $\mathrm{BP}$ & GO:0044262 & $\begin{array}{c}\text { cellular carbohydrate metabolic } \\
\text { process }\end{array}$ & 106 & 11 & 2.75 & 4.00 & $8.1 \times 10^{-5}$ & $3.6 \times 10^{-2}$ \\
\hline Glu-Xyl-120 & Down & MF & GO:0004553 & $\begin{array}{l}\text { hydrolase activity, hydrolyzing } \\
\text { O-glycosyl compounds }\end{array}$ & 179 & 21 & 4.54 & 4.62 & $2.6 \times 10^{-9}$ & $8.0 \times 10^{-6}$ \\
\hline \multirow[t]{5}{*}{ Glu-46-70 } & \multirow[t]{2}{*}{ Up } & $\mathrm{CC}$ & GO:0044446 & intracellular organelle part & 1187 & 220 & 152.43 & 1.44 & $7.3 \times 10^{-11}$ & $2.3 \times 10^{-7}$ \\
\hline & & $\mathrm{BP}$ & GO:0006364 & rRNA processing & 136 & 43 & 17.46 & 2.46 & $5.6 \times 10^{-9}$ & $5.8 \times 10^{-6}$ \\
\hline & \multirow[t]{3}{*}{ Down } & $\mathrm{BP}$ & GO:0019752 & carboxylic acid metabolic process & 371 & 115 & 70.45 & 1.63 & $5.3 \times 10^{-9}$ & $8.7 \times 10^{-6}$ \\
\hline & & $\mathrm{BP}$ & GO:0046395 & carboxylic acid catabolic process & 83 & 36 & 15.76 & 2.28 & $2.4 \times 10^{-7}$ & $1.2 \times 10^{-4}$ \\
\hline & & $\mathrm{BP}$ & GO:1901565 & $\begin{array}{l}\text { organonitrogen compound } \\
\text { catabolic process }\end{array}$ & 230 & 75 & 43.68 & 1.72 & $3.3 \times 10^{-7}$ & $1.3 \times 10^{-4}$ \\
\hline \multirow[t]{4}{*}{ Glu-70-120 } & \multirow[t]{3}{*}{ Up } & $\mathrm{CC}$ & GO:0044444 & cytoplasmic part & 1220 & 260 & 156.19 & 1.66 & 0 & 0 \\
\hline & & $\mathrm{BP}$ & GO:1901564 & $\begin{array}{l}\text { organonitrogen compound } \\
\text { metabolic process }\end{array}$ & 1486 & 279 & 190.25 & 1.47 & $1.6 \times 10^{-15}$ & $1.6 \times 10^{-12}$ \\
\hline & & $\begin{array}{l}\mathrm{CC} \\
\mathrm{CC}\end{array}$ & $\begin{array}{l}\text { GO:0044429 } \\
\text { GO:0005634 }\end{array}$ & $\begin{array}{c}\text { mitochondrial part } \\
\text { nucleus }\end{array}$ & $\begin{array}{c}205 \\
1293\end{array}$ & $\begin{array}{c}67 \\
217\end{array}$ & $\begin{array}{l}26.25 \\
135.76\end{array}$ & $\begin{array}{l}2.55 \\
1.60\end{array}$ & $\begin{array}{l}3.2 \times 10^{-14} \\
2.2 \times 10^{-16}\end{array}$ & $\begin{array}{l}2.0 \times 10^{-11} \\
6.9 \times 10^{-13}\end{array}$ \\
\hline & Down & $\mathrm{BP}$ & GO:0051171 & $\begin{array}{l}\text { regulation of nitrogen compound } \\
\text { metabolic process }\end{array}$ & 665 & 113 & 69.82 & 1.62 & $2.5 \times 10^{-8}$ & $1.1 \times 10^{-5}$ \\
\hline \multirow[t]{6}{*}{ Xyl-46-70 } & \multirow[t]{3}{*}{ Up } & $\mathrm{CC}$ & GO:1990904 & ribonucleoprotein complex & 380 & 76 & 27.29 & 2.78 & 0 & 0 \\
\hline & & $\mathrm{BP}$ & GO:0042254 & ribosome biogenesis & 189 & 60 & 13.57 & 4.42 & 0 & 0 \\
\hline & & $\mathrm{BP}$ & GO:0016072 & rRNA metabolic process & 153 & 44 & 10.99 & 4.00 & $2.2 \times 10^{-16}$ & $8.6 \times 10^{-14}$ \\
\hline & \multirow[t]{3}{*}{ Down } & $\mathrm{BP}$ & GO:1901565 & $\begin{array}{l}\text { organonitrogen compound } \\
\text { catabolic process }\end{array}$ & 230 & 41 & 19.57 & 2.10 & $2.8 \times 10^{-6}$ & $8.8 \times 10^{-3}$ \\
\hline & & MF & GO:0048038 & quinone binding & 13 & 7 & 1.11 & 6.33 & $3.4 \times 10^{-5}$ & $3.1 \times 10^{-2}$ \\
\hline & & $\mathrm{BP}$ & GO:0006637 & acyl-CoA metabolic process & 23 & 9 & 1.96 & 4.60 & $6.0 \times 10^{-5}$ & $3.1 \times 10^{-2}$ \\
\hline \multirow[t]{4}{*}{ Xyl-70-120 } & \multirow[t]{2}{*}{ Up } & $\mathrm{CC}$ & GO:0005737 & cytoplasm & 1677 & 296 & 198.99 & 1.49 & 0 & 0 \\
\hline & & $\mathrm{BP}$ & GO:0009150 & $\begin{array}{l}\text { purine ribonucleotide metabolic } \\
\text { process }\end{array}$ & 106 & 39 & 12.58 & 3.10 & $1.7 \times 10^{-11}$ & $1.8 \times 10^{-8}$ \\
\hline & \multirow[t]{2}{*}{ Down } & $\mathrm{BP}$ & GO:0042254 & ribosome biogenesis & 189 & 53 & 20.88 & 2.54 & $3.9 \times 10^{-11}$ & $4.0 \times 10^{-8}$ \\
\hline & & $\mathrm{BP}$ & GO:0016070 & RNA metabolic process & 1029 & 173 & 113.66 & 1.52 & $2.0 \times 10^{-10}$ & $1.5 \times 10^{-7}$ \\
\hline
\end{tabular}

Gene ontology-based enrichment analysis further revealed significant downregulation of genes associated with cellular respiration (GO:0045333: FDR $=7.4 \times 10^{-3}$ ) at $46 \mathrm{~h} \mathrm{sam-}$ pling point and cellular carbohydrate metabolic process (GO:0044262; FDR $=3.6 \times 10^{-2}$ ) at $70 \mathrm{~h}$ sampling point in $S$. podzolica grown on glucose relative to xylose (Table 2). However, a more comprehensive comparison of carbohydrate metabolism under the two sugars is presented below. Glycolysis, Pentose Phosphate, and Glucuronate Interconversion Pathways and TCA Cycle during Initial Growth of Saitozyma Podzolica DSM 27192 on Glucose Relative to Xylose

To further elucidate the functional difference between transcriptome profiles of glucose and xylose grown S. podzolica, we, in addition to gene ontology, scanned relevant metabolic pathways associated with the overexpressed genes at $22 \mathrm{~h}$ time point using against KEGG ortholog [32]. Using Pathview [65], KO identities of the differentially expressed genes were mapped against several important pathways (Figure 5a,b). No significant difference was observed for the comparison of TCA cycle between the two transcriptome profiles during the initial growth of the yeast (time point $22 \mathrm{~h}$ : Figure 5b). By contrast, two genes each of glycolysis and pentose phosphate pathway show significant differences between 
the two conditions. In glycolysis, EHS25_004951 $\left(\log 2 \mathrm{FC}=1.2\right.$ and FDR $\left.=-5.0 \times 10^{-4}\right)$ and EHS25_006131 $\left(\log 2 \mathrm{FC}=-1.6\right.$ and FDR $\left.=2.0 \times 10^{-2}\right)$ coding acetyl-CoA synthetase (EC:6.2.1.1) and alcohol dehydrogenase, propanol-preferring (EC:1.1.1.1), respectively, were significantly induced in xylose relative to glucose condition (Figure 5a). The former catalyses the activation of acetate to acetyl-CoA while the latter catalyses the first step of alcohol degradation. Previous studies in S. cerevisiae [66] showed that the expression of acetyl-CoA synthetase gene is strongly suppressed under carbon source limitation and high glucose concentration. Contrary to our observation, however, no significant difference exists in expression of the gene between recombinant xylose-utilizing S. cerevisiae grown on glucose and xylose [67]. Our observation, suppression, and overexpression of the alcohol dehydrogenase gene under glucose and xylose, respectively, was reported in these studies $[66,67]$. The overexpression of acetyl-CoA synthetase gene under xylose could prove significant for developing fermentation strategies on different $\mathrm{C}$-sources in $\mathrm{S}$. podzolica.

Of the fifteen genes associated with pentose phosphate and glucuronate interconversions, glycolysis pathways and TCA cycle, only two genes have been overexpressed in glucose relative xylose grown yeast over the duration of the batch fed process (Figure 5). By contrast, five genes of the pentose and glucuronate interconversion and two of pentose phosphate pathways were significantly suppressed under glucose compared to growth under xylose. As expected, significant overrepresentation of genes encoding D-xylulose reductase/L-iditol 2-dehydrogenase (EC:1.1.1.9/EC:1.1.1.14), EHS25_007055 $\left(\log 2 \mathrm{FC}=-5.1\right.$ and FDR $\left.=2.0 \times 10^{-51}\right)$ and EHS25_005852 $(\log 2 \mathrm{FC}=-3.8$ and FDR $=4.0 \times 10^{-31}$ ), which catalyses the oxidation of xylitol to D-xylulose [69] was observed in xylose relative to glucose (Figure 5a). Xylulokinase (EC:2.7.1.17), EHS25_008536 $\left(\log 2 \mathrm{FC}=-4.7\right.$ and FDR $\left.=5.0 \times 10^{-37}\right)$, which catalyses xylulose to xylulose-5-phosphate phosphorylation was also overrepresented under xylose.

Comparison of the gene expression during fed-batch cultivation for the individual sugars revealed that 5308 and 3666 genes were differentially expressed (FDR $<0.05)$ across the three time points in glucose and xylose, respectively (Figure 4c). Of these 8,974 genes that were differentially expressed in both sugars, $\sim 2.8 \%$ (250) were observed among all time points and both sugars (Figure 4c). Higher numbers of genes (3217), comprising 1339 and 1788 up and downregulated genes, were observed to be differentially expressed at 46 relative to the $70 \mathrm{~h}$ time point in glucose grown cultures compared to those grown on xylose (Figure 4d). By contrast, a greater number of genes (2258), comprising 1092 and 1166 genes were significantly (FDR < 0.05) up and downregulated, respectively, at 70 relative to $120 \mathrm{~h}$ time point in xylose compared to glucose grown cultures. Evaluation of the functional basis of the DEGs for the various profile comparisons, however, showed different metabolic patterns during growth of the oleaginous yeast on glucose and xylose (Table 2). For instance, at 46 relative to $70 \mathrm{~h}$ time point, 115 genes associated with the carboxylic acid metabolic processes $\left(\mathrm{FDR}=8.7 \times 10^{-6}\right)$ were downregulated under glucose compared to 9 genes of acyl-CoA metabolic process $\left(\mathrm{FDR}=3.1 \times 10^{-2}\right)$ for the same time point in xylose (Table 2).

Interestingly, among genes linked to induction of oil production (Figure 6), only ATP citrate lyase (ACL) gene showed significant over expression in both glucose (EHS25_008599; $\log 2 \mathrm{FC}=1.20$ and FDR $=5.4 \times 10^{-4}$ ) and xylose (EHS25_008599; $\log 2 \mathrm{FC}=0.92$ and FDR $=2.11 \times 10^{-2}$ ) at 70 -h time point. ACL catalyses the cleavage of citrate into acetyl$\mathrm{CoA}$ and oxaloacetate (OAA). Preference to this pathway as well as the cycling of carbon $(\mathrm{OAA} \rightarrow$ pyruvate $\rightarrow$ citrate; Figure 6$)$ is characteristic of oleaginous yeast $[77,78]$. Genes of acetyl-CoA carboxylase (ACC), fatty acid synthase subunit alpha (FASI; EHS25_002838; $\log 2 \mathrm{FC}=1.92$ and FDR $\left.=5.35 \times 10^{-5}\right)$ \& beta (FASII; EHS25_002837; $\log 2 \mathrm{FC}=-1.58$ and FDR $=8.00 \times 10^{-10}$ ) and isocitrate dehydrogenase subunit $1 \& 2$ (IDH1 \& 2) were significantly overexpressed (FDR $>0.05$ ) at 70 relative to $46 \mathrm{~h}$ time point (Figure 6) only in glucose grown cultures (Table S2). The above genes were also upregulated in xylose grown cultures, but outside the significance threshold of this analysis. ACC catalyses 
the carboxylation of acetyl-CoA (A-CoA) to malonyl-CoA (M-CoA) while FAS complex catalyses fatty acid synthesis through a series of reactions (condensation-reductiondehydration), involving A-CoA, M-CoA, and NADPH [79]. However, greater suppression of isocitrate dehydrogenase (ICDH) gene (EHS25_006623) was observed in glucose $\left(\log 2 \mathrm{FC}=-1.7\right.$ and FDR $\left.=4.37 \times 10^{-9}\right)$ relative to xylose $(\log 2 \mathrm{FC}=-0.79$ and $\mathrm{FDR}=2.4 \times 10^{-2}$ ) grown cultures at 46- relative to 70-h sampling point. By contrast, AMP deaminase (AMPD) gene (EHS25_008352) was not significantly overexpressed under both sugars. The mechanism of oil production initiation in oleaginous yeast has been variously linked to nutrient limitation, including nitrogen [80-82]. Nitrogen starvation induces an increase in AMPD activity leading to depletion of adenosine monophosphate (AMP) thereby inhibiting ICDH and as a consequence the accumulation of citrate [80].
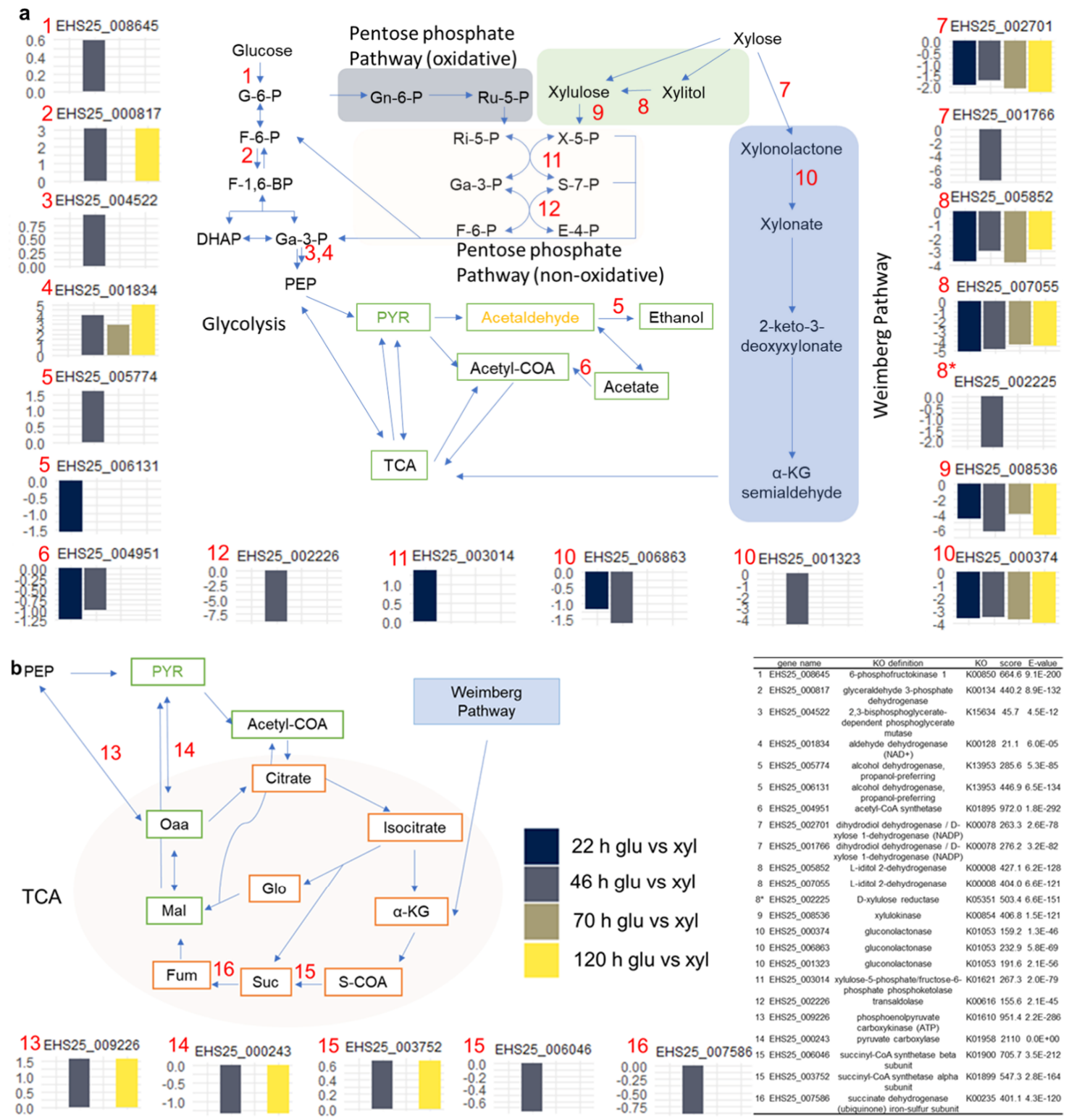

Figure 5. Overview of expression pattern of genes associated with enzymes of the central carbon metabolism of Saitozyma podzolica DSM 27192 on glucose relative to xylose. (a) glycolysis, pentose phosphate and putative Weimberg pathways. (b) TCA cycle. Differentially expressed genes (FDR < 0.05) are indicated by red numbers in the pathways and bar plots of $\log 2 \mathrm{FC}$ values for glucose relative to xylose linked to these numbers. Green and light brown boxes indicate pathways that occur in both cytoplasm and mitochondria, and those occurring exclusively in the mitochondrion, respectively. Figure was adapted from [68]. Asterisk ${ }^{* \prime}$ indicates that D-xylulose reductase is also called xylitol dehydrogenase. 
Aside from the dynamics of AMPD and ICDH above, several studies have reported the expression profiles of the 'oleagenic' genes in yeast during oil accumulation under various conditions. For instance, in Trichosporon oleaginosus grown under two carbon sources and nitrogen or phosphate limitations, only ACL and FAS genes were significantly overrepresented (FDR $<0.05$ ) in the yeast grown in xylose under nitrogen limitation relative to the control cultures and only ACL gene significantly overrepresented (FDR $<0.05)$ in $\mathrm{N}$-acetyl glucosamine grown yeast under nitrogen limitation relative to the control cultures [83]. By contrast, the current study did not reveal significant differences in the expression of these genes in glucose compared to xylose grown S. podzolica under nitrogen limitation (sampling time $76 \mathrm{~h}$; Figure 1). Apparently, the observed overexpression (FDR $<0.05)$ of the ACL gene (also reported in [83]) and suppression (FDR < 0.05) of the ICDH gene likely underpin lipid accumulation under nitrogen limitation in S. podzolica.

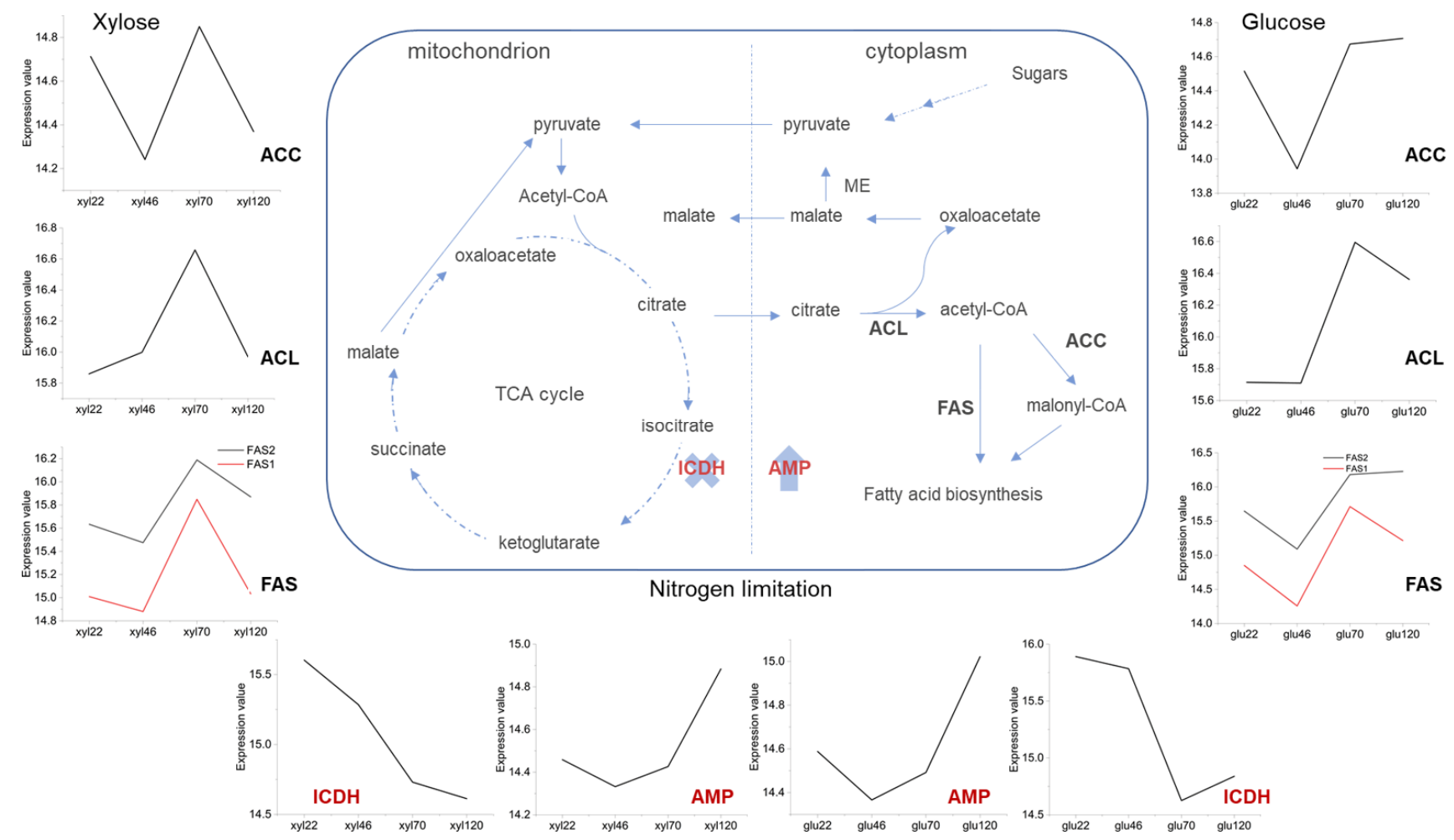

Figure 6. Profiles of major genes linked to initiation and production of single cell oil during growth of Saitozyma podzolica DSM 27192 on glucose and xylose under nitrogen limitation. ACC, ACL, AMP, FAS and ICDH refer to acetyl-CoA carboxylase, ATP citrate lyase, AMP deaminase, fatty acid synthase and isocitrate dehydrogenase respectively. Line graphs show expression trajectories of genes encoding ACC, ACL, AMP, FAS and ICDH. X and arrow up indicate suppression of ICDH and overexpression of AMP.

\subsection{Temporal Dynamics of S. podzolica DSM 27192 Genes Grown under Glucose and Xylose}

To identify the gene expression profile changes over the duration of S. podzolica DSM 27192 growth on glucose and xylose under fed-batch condition (46, 70 and $120 \mathrm{~h}$ ), we implemented the maSigPro algorithm based on alfa threshold value of 0.5 . The analysis revealed 4782 genes ( $\sim 7 \%$ of the expressed genes) showing significant differential expression (FDR $<0.05)$ during the continuous cultivation experiment. The co-expressed genes were partitioned based on the $K$-means cluster method ( $k=6$ and $\left.R^{2} \geq 0.7\right)$ into six distinct expression clusters (Figure 7). Clusters 1 and 5, comprising 867 (18.13\% of the co-expressed genes) and 1076 (22.5\% of the co-expressed genes) genes, respectively, show opposite trajectories, with expression values in the former cluster decreasing at $70 \mathrm{~h}$ before then peaking again at $120 \mathrm{~h}$. Evaluation of genes in cluster 1 revealed an overrepresentation (FDR < 0.05 ) of two biological processes (BP), ribosome biogenesis, (GO:0042254) and 
RNA metabolic process (GO:0016070), as well as one cellular component (CC) function, nuclear lumen (GO:0031981), suggesting a possible suppression of translational machinery in response to nitrogen limitation. Previous studies have reported the influence of nutrients availability, including nitrogen, on ribosome biogenesis [84-86]. Specifically, proteome study of the oleaginous yeast Rhodotorula toruloides grown in glucose and xylose revealed significant depletion of genes associated with ribosome biogenesis [87].

By contrast, two CC functions, cytoplasm (GO:0005737) and proteasome complex (GO:0000502; also included in GO:0005737) and one BP, ribose phosphate metabolic process (GO:0019693; also included in GO:0005737) were significantly overrepresented (FDR < 0.05) among genes belonging to cluster 5 (Figure 7). Upregulation of these processes provides insight into the innate evolutionary strategy adapted by the yeast to salvage the effects of nitrogen-starvation-induced stress. For instance, overrepresentation of the proteasome complex indicates increased destructive activity of the proteasome system on cyclin, which prevents organelle dismemberment and cell destruction under nitrogen limitation [88]. The potential of cyclin activity is also indicated by the upregulation of genes of cyclin (EHS25_000231) and cyclin binding protein (EHS25_007811), included among genes associated with cytoplasmic function (Figure 7; Table S3). In addition, the increased expression of genes linked to energy production and other metabolic pathways (Table S3) under complete nitrogen starvation indicates robust metabolic capacity of the yeast at the onset of lipid accumulation.
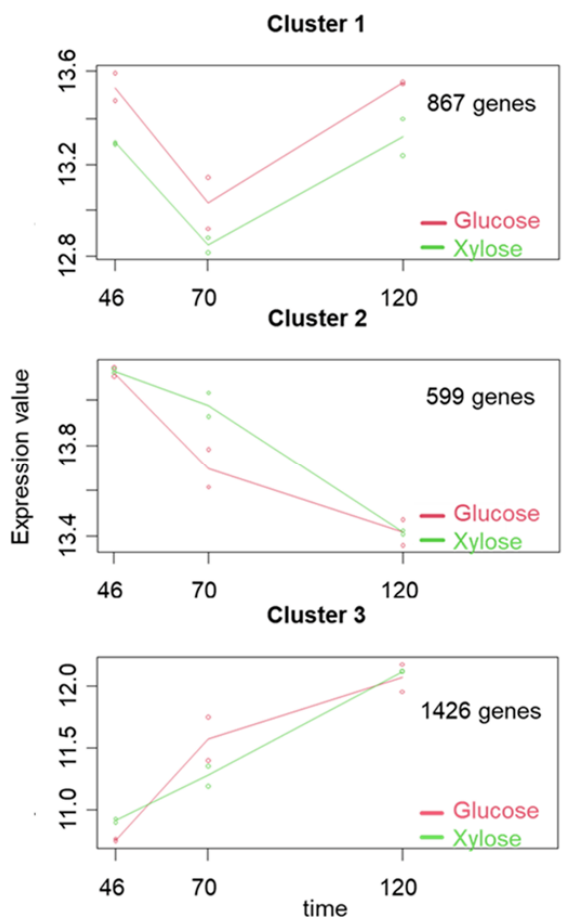
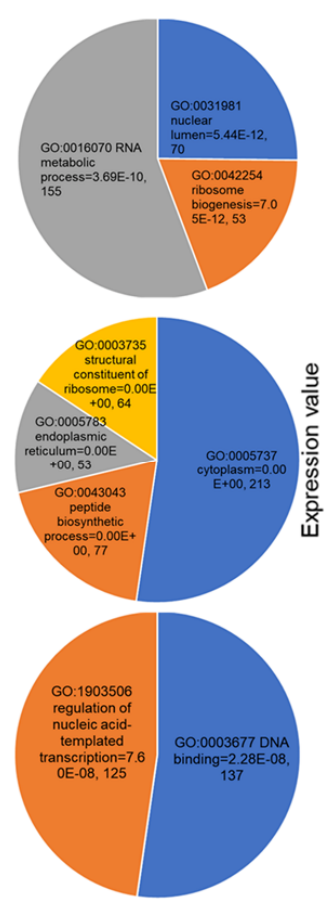
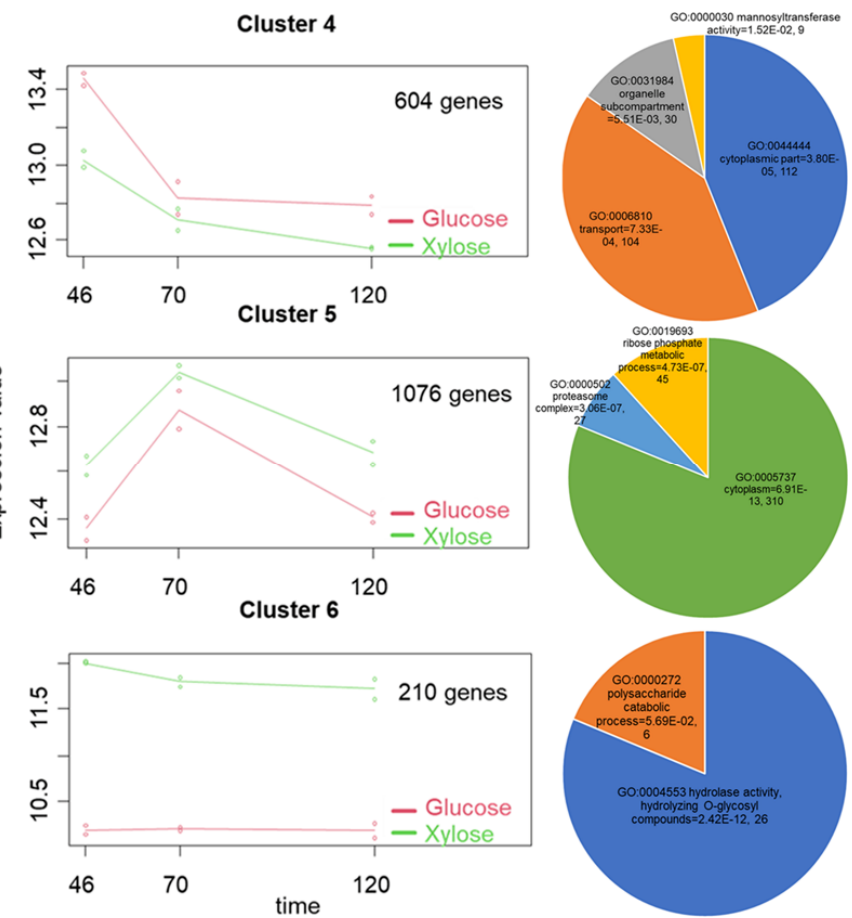

Figure 7. Trajectories and GO functional enrichment of expressed gene clusters in Saitozyma podzolica DSM 27192 cultivated glucose and xylose. Profiles of six clusters over three time points (46, 70 and $120 \mathrm{~h}$ ) were generated using maSigPro and gene ontology-based functional association was plotted in the adjacent pie charts. In the line graphs, the dots per time point represent the mean expression values per biological replicate. Gene ontology (GO), false discovery rate values and number of genes associated with each GO are shown in the pie charts.

Similar reverse trajectories were also observed between clusters 2 (599 genes; $12.5 \%$ of the co-expressed genes) and 3 (1426 genes; $29.8 \%$ of the co-expressed genes) showing trends of decrease and increase, respectively, during growth of S. podzolica DSM 27192 on glucose and xylose. Cluster 2 is significantly (FDR < 0.05) enriched in two CC, one $\mathrm{BP}$ and an MF, structural constituent of ribosome (GO:0003735), while cluster 3 shows significant overrepresentation (FDR < 0.05) in genes linked to one BP (GO:1903506; regu- 
lation of nucleic acid-templated transcription) and one MF (GO:0003677; DNA binding; Figure 7). As discussed above, nitrogen limitation induces the downregulation of ribosome biogenesis. However, in contrast to the trajectory of cluster 1, the depletion of the structural constituent of ribosome and peptide biosynthetic process (GO:0043043) persisted in cluster 2, corresponding to the phase of maximum oil accumulation (72-120-h time point) in $S$. podzolica DSM 27192 [10]. Although not conclusive at present, our study indicates a clearer association of lipogenesis and downregulation of ribosomes, contrary to the suggestion of greater association with growth activity in R. toruloides [87]. This hypothesis is further supported by various 'omics' studies under nitrogen limitation in Yarrowia lipolytica [89,90].

Cluster 4 with $604(12.6 \%)$ genes showed a similar rapid drop in expression values as with cluster 1 at time point 70, but the expression levels remained low through to time point $120 \mathrm{~h}$ in both glucose and xylose cultures (Figure 7). Evaluation of the temporal dynamics represented in this cluster revealed a predominance of genes linked to mannosyltransferase activity (GO:0000030), organelle compartment (GO:0031984), transport and cytoplasm GOs with depletion of nitrogen and the onset of lipogenesis (Figure 7). Specifically, there was a decrease in the expression of several key genes linked to protein $N$-glycosylation [91-93] such as the putative $\alpha-1,2-, \alpha-1,3-, \alpha-1,6-$, and $\beta-1,4-$ mannosyltransferases under nitrogen limitation in cultures grown on both glucose and xylose (Table S3). Apparently, these genes are involved in Glycosylphosphatidylinositol (GPI) anchoring as suggested by a corresponding reduction in the expression of genes propagating the enriched organelle compartment, transport, and cytoplasm GOs. For instance, genes of phosphatidylinositolglycan biosynthesis S protein (EHS25_000085; Table S3), a key component of GPI transamidase complex [94], transport protein bet1 (EHS25_004488) and endoplasmic reticulum (ER)-Golgi intermediate compartment (ERGIC) protein (EHS25_004458), both involved in shuttle between endoplasmic reticulum and Golgi membrane $[95,96]$ further support the downregulation of ER-to-Golgi activities during nitrogen-limited lipid accumulation. However, the precise implication of these findings is subject to further investigation.

Finally, cluster 6 ( 210 genes; $4.4 \%$ ) exhibited uniform expression values across the three time points in both sugars (Figure 7). However, higher gene expression values were observed for culture grown on xylose relative to glucose, consistent with the observed significant upregulation of hydrolase activity, hydrolysing O-glycosyl compounds (GO:0004553) throughout the cultivation period in xylose compared to glucose grown cultures (discussed above; Tables 1 and 2).

\section{Conclusions}

Previous studies have reported the ability of S. podzolica to produce various biochemicals, including single-cell oils and sugar acids from different carbon sources [10]. Thus, we evaluated the transcriptome profiles in Saitozyma podzolica DSM 27192 cultivated on glucose and xylose under batch and continuous processes by RNA-seq analysis. Our transcriptomic analysis revealed a wide range of transcriptome level differences between $S$. podzolica grown on glucose and xylose. We showed that several putative sugar transporter genes, including transporters of other substrates, were overexpressed distinctively on either glucose or xylose, albeit in greater numbers in the latter. This study also reports xylose induction of genes associated with carbohydrate utilization, a feature which could be harnessed potentially for enhanced cultivation of the yeast on complex substrates. We also discussed the presence of putative genes associated with the initial steps of the Weimberg pathway, which likely underpin the efficient utilization of xylose and production of xylonic acid by S. podzolica. However, the basis of carbon flux partitioning between the above pathway and the non-oxidative pentose phosphate pathway remains unclear, given that genes coding for enzymes of both pathways were significantly expressed under xylose cultivation. Our study contributes to a better understanding of the genetic basis of glucose and xylose growth and production of single cell oil by S. podzolica. These data will contribute to further development of efficient fermentation strategies and development of S. podzolica strains with superior features for enhanced biotechnological applications. 
Supplementary Materials: The following are available online at https:/ / www.mdpi.com/article/10 .3390/jof7090758/s1, Figure S1: Differential gene expression during initial growth (22 h time point) of Saitozyma podzolica DSM 27192 on glucose compared to xylose, Table S1: Differentially expressed transporter genes in Saitozyma podzolica DSM 27192 grown on glucose compared to xylose, Table S2: Functional enrichment of differentially expressed genes during continuous cultivation of Saitozyma podzolica DSM 27192 on glucose compared to xylose, Table S3: GO functional enrichment of expressed gene clusters in Saitozyma podzolica DSM 27192 grown on glucose and xylose.

Author Contributions: Conceptualization, H.A., K.O. and O.G.; methodology, H.A. And O.G.; software, H.A.; formal analysis, H.A.; investigation, H.A.; resources, A.N. and K.O.; data curation, H.A.; writing—original draft preparation, H.A.; writing—review and editing, A.N., H.A., K.O. and O.G.; visualization, H.A.; project administration, A.N. and K.O.; funding acquisition, K.O. All authors have read and agreed to the published version of the manuscript.

Funding: Bioeconomy International BMBF (Grant \#031B0452) supported OG.

Institutional Review Board Statement: Not applicable.

Informed Consent Statement: Not applicable.

Data Availability Statement: RNA-seq data generated and reported in this study have been deposited into NCBI Sequence Read Archive (SRA) database under the BioProject ID: PRJNA755891.

Acknowledgments: We acknowledge support by Deutsche Forschungsgemeinschaft and the KITPublication Fund of the Karlsruhe Institute of Technology.

Conflicts of Interest: The authors declare no conflict of interest. The funders had no role in the design of the study; in the collection, analyses, or interpretation of data; in the writing of the manuscript, or in the decision to publish the results.

\section{References}

1. United Nations, Department of Economic and Social Affairs, Population Division. World Population Prospects 2019: Highlights; United Nations: New York, NY, USA, 2019; p. 40.

2. Ratledge, C. Fatty acid biosynthesis in microorganisms being used for single cell oil production. Biochimie 2004, 86, 807-815. [CrossRef] [PubMed]

3. Yousuf, A.; Sannino, F.; Addorisio, V.; Pirozzi, D. Microbial conversion of olive oil mill wastewaters into lipids suitable for biodiesel production. J. Agric. Food Chem. 2010, 58, 8630-8635. [CrossRef] [PubMed]

4. Ling, J.; Nip, S.; Shim, H. Enhancement of lipid productivity of Rhodosporidium toruloides in distillery wastewater by increasing cell density. Bioresour. Technol. 2013, 146, 301-309. [CrossRef]

5. Kot, A.; Błażejak, S.; Kurcz, A.; Bryś, J.; Gientka, I.; Bzducha-Wróbel, A.; Maliszewska, M.; Reczek, L. Effect of initial pH of medium with potato wastewater and glycerol on protein, lipid and carotenoid biosynthesis by Rhodotorula glutinis. Electron. J. Biotechnol. 2017, 27, 25-31. [CrossRef]

6. Li, Q.; Du, W.; Liu, D. Perspectives of microbial oils for biodiesel production. Appl. Microbiol. Biotechnol. 2008, 80, 749-756. [CrossRef]

7. Ageitos, J.M.; Vallejo, J.; Veiga-Crespo, P.; Villa, T.G. Oily yeasts as oleaginous cell factories. Appl. Microbiol. Biotechnol. 2011, 90, 1219-1227. [CrossRef]

8. Aliyu, H.; Gorte, O.; Zhou, X.; Neumann, A.; Ochsenreither, K. In silico proteomic analysis provides insights into phylogenomics and plant biomass deconstruction potentials of the tremelalles. Front. Bioeng. Biotechnol. 2020, 8, 226. [CrossRef]

9. Aliyu, H.; Gorte, O.; de Maayer, P.; Neumann, A.; Ochsenreither, K. Genomic insights into the lifestyles, functional capacities and oleagenicity of members of the fungal family Trichosporonaceae. Sci. Rep. 2020, 10, 1-12. [CrossRef] [PubMed]

10. Gorte, O.; Kugel, M.; Ochsenreither, K. Optimization of carbon source efficiency for lipid production with the oleaginous yeast Saitozyma podzolica DSM 27192 applying automated continuous feeding. Biotechnol. Biofuels 2020, 13, 1-17. [CrossRef]

11. Meesters, P.A.E.P.; Huijberts, G.N.M.; Eggink, G. High-cell-density cultivation of the lipid accumulating yeast Cryptococcus curvatus using glycerol as a carbon source. Appl. Microbiol. Biotechnol. 1996, 45, 575-579. [CrossRef]

12. Fei, Q.; O'Brien, M.; Nelson, R.; Chen, X.; Lowell, A.; Dowe, N. Enhanced lipid production by Rhodosporidium toruloides using different fed-batch feeding strategies with lignocellulosic hydrolysate as the sole carbon source. Biotechnol. Biofuels 2016, 9, 1-12. [CrossRef] [PubMed]

13. Poontawee, R.; Limtong, S. Feeding strategies of two-stage fed-batch cultivation processes for microbial lipid production from sugarcane top hydrolysate and crude glycerol by the oleaginous red yeast Rhodosporidiobolus fluvialis. Microorganisms 2020, 8, 151. [CrossRef] [PubMed]

14. Gírio, F.; Fonseca, C.; Carvalheiro, F.; Duarte, L.; Marques, S.; Lukasik, R. Hemicelluloses for fuel ethanol: A review. Bioresour. Technol. 2010, 101, 4775-4800. [CrossRef] [PubMed] 
15. Schulze, I.; Hansen, S.; Großhans, S.; Rudszuck, T.; Ochsenreither, K.; Syldatk, C.; Neumann, A. Characterization of newly isolated oleaginous yeasts-Cryptococcus podzolicus, Trichosporon porosum and Pichia segobiensis. AMB Express 2014, 4, 24. [CrossRef]

16. Qian, X.; Gorte, O.; Chen, L.; Zhang, W.; Dong, W.; Ma, J.; Jiang, M.; Xin, F.; Ochsenreither, K. Co-production of single cell oil and gluconic acid using oleaginous Cryptococcus podzolicus DSM 27192. Biotechnol. Biofuels 2019, 12, 1-9. [CrossRef] [PubMed]

17. Gorte, O.; Hollenbach, R.; Papachristou, I.; Steinweg, C.; Silve, A.; Frey, W.; Syldatk, C.; Ochsenreither, K. Evaluation of downstream processing, extraction, and quantification strategies for single cell oil produced by the oleaginous yeasts Saitozyma podzolica DSM 27192 and Apiotrichum porosum DSM 27194. Front. Bioeng. Biotechnol. 2020, 8, 355. [CrossRef]

18. Andrews, S. FastQC: A Quality Control Tool for High Throughput Sequence Data; Babraham Institute: Cambridge, UK, 2010.

19. Chen, S.; Zhou, Y.; Chen, Y.; Gu, J. Fastp: An ultra-fast all-in-one FASTQ preprocessor. Bioinformatics 2018, 34, i884-i890. [CrossRef]

20. Aliyu, H.; Gorte, O.; Neumann, A.; Ochsenreither, K. Draft genome sequence of the oleaginous yeast Saitozyma podzolica (syn. Cryptococcus podzolicus) DSM 27192. Microbiol. Resour. Announc. 2019, 8, e01676-18. [CrossRef]

21. Kim, D.; Langmead, B.; Salzberg, S.L. HISAT: A fast spliced aligner with low memory requirements. Nat. Methods 2015, 12, 357-360. [CrossRef]

22. Danecek, P.; Bonfield, J.K.; Liddle, J.; Marshall, J.; Ohan, V.; Pollard, M.O.; Whitwham, A.; Keane, T.; McCarthy, S.A.; Davies, R.M.; et al. Twelve years of SAMtools and BCFtools. GigaScience 2021, 10. [CrossRef]

23. Pertea, M.; Pertea, G.M.; Antonescu, C.M.; Chang, T.-C.; Mendell, J.T.; Salzberg, S.L. StringTie enables improved reconstruction of a transcriptome from RNA-seq reads. Nat. Biotechnol. 2015, 33, 290-295. [CrossRef]

24. Pertea, M.; Kim, D.; Pertea, G.M.; Leek, J.T.; Salzberg, S.L. Transcript-level expression analysis of RNA-seq experiments with HISAT, StringTie and Ballgown. Nat. Protoc. 2016, 11, 1650-1667. [CrossRef]

25. Pertea, G.; Pertea, M. GFF utilities: GffRead and GffCompare. F1000Research 2020, 9, 304. [CrossRef]

26. Love, M.I.; Huber, W.; Anders, S. Moderated estimation of fold change and dispersion for RNA-seq data with DESeq2. Genome Biol. 2014, 15, 550. [CrossRef]

27. Ge, S.X.; Son, E.W.; Yao, R. iDEP: An integrated web application for differential expression and pathway analysis of RNA-Seq data. BMC Bioinform. 2018, 19, 1-24. [CrossRef]

28. Nueda, M.J.; Tarazona, S.; Conesa, A. Next maSigPro: Updating maSigPro bioconductor package for RNA-seq time series. Bioinformatics 2014, 30, 2598-2602. [CrossRef]

29. Conesa, A.; Nueda, M.J.; Ferrer, A.; Talón, M. maSigPro: A method to identify significantly differential expression profiles in time-course microarray experiments. Bioinformatics 2006, 22, 1096-1102. [CrossRef]

30. Li, W.; Godzik, A. Cd-hit: A fast program for clustering and comparing large sets of protein or nucleotide sequences. Bioinformatics 2006, 22, 1658-1659. [CrossRef] [PubMed]

31. Törönen, P.; Medlar, A.; Holm, L. PANNZER2: A rapid functional annotation web server. Nucleic Acids Res. 2018, 46, W84-W88. [CrossRef]

32. Aramaki, T.; Blanc-Mathieu, R.; Endo, H.; Ohkubo, K.; Kanehisa, M.; Goto, S.; Ogata, H. KofamKOALA: KEGG Ortholog assignment based on profile HMM and adaptive score threshold. Bioinformatics 2020, 36, 2251-2252. [CrossRef]

33. Huerta-Cepas, J.; Forslund, K.; Coelho, L.P.; Szklarczyk, D.; Jensen, L.J.; von Mering, C.; Bork, P. Fast genome-wide functional annotation through orthology assignment by eggNOG-Mapper. Mol. Biol. Evol. 2017, 34, 2115-2122. [CrossRef] [PubMed]

34. Jones, P.; Binns, D.; Chang, H.Y.; Fraser, M.; Li, W.; McAnulla, C.; McWilliam, H.; Maslen, J.; Mitchell, A.; Nuka, G.; et al. InterProScan 5: Genome-scale protein function classification. Bioinformatics 2014, 30, 1236-1240. [CrossRef]

35. Liao, Y.; Wang, J.; Jaehnig, E.J.; Shi, Z.; Zhang, B. WebGestalt 2019: Gene set analysis toolkit with revamped UIs and APIs. Nucleic Acids Res. 2019, 47, W199-W205. [CrossRef]

36. Marchler-Bauer, A.; Derbyshire, M.K.; Gonzales, N.R.; Lu, S.; Chitsaz, F.; Geer, L.Y.; Geer, R.C.; He, J.; Gwadz, M.; Hurwitz, D.I.; et al. CDD: NCBI's conserved domain database. Nucleic Acids Res. 2015, 43, D222-D226. [CrossRef]

37. The UniProt Consortium. UniProt: The universal protein knowledgebase in 2021. Nucleic Acids Res. 2021, 49, D480-D489. [CrossRef]

38. Saier, M.H.; Reddy, V.S.; Moreno-Hagelsieb, G.; Hendargo, K.J.; Zhang, Y.; Iddamsetty, V.; Lam, K.J.K.; Tian, N.; Russum, S.; Wang, J.; et al. The Transporter Classification Database (TCDB): 2021 update. Nucleic Acids Res. 2021, 49, D461-D467. [CrossRef]

39. Krogh, A.; Larsson, B.; von Heijne, G.; Sonnhammer, E.L. Predicting transmembrane protein topology with a hidden Markov model: Application to complete genomes. J. Mol. Biol. 2001, 305, 567-580. [CrossRef]

40. Di Tommaso, P.; Moretti, S.; Xenarios, I.; Orobitg, M.; Montanyola, A.; Chang, J.-M.; Taly, J.-F.; Notredame, C. T-coffee: A web server for the multiple sequence alignment of protein and RNA sequences using structural information and homology extension. Nucleic Acids Res. 2011, 39, W13-W17. [CrossRef]

41. Nguyen, L.-T.; Schmidt, H.A.; von Haeseler, A.; Minh, B.Q. IQ-TREE: A Fast and effective stochastic algorithm for estimating maximum-likelihood phylogenies. Mol. Biol. Evol. 2014, 32, 268-274. [CrossRef]

42. Iwanicki, N.S.; Júnior, I.D.; Eilenberg, J.; De Fine Licht, H.H. Comparative RNAseq analysis of the insect-pathogenic fungus Metarhizium anisopliae reveals specific transcriptome signatures of filamentous and yeast-like development. G3 Genes Genomes Genet. 2020, 10, 2141-2157. [CrossRef]

43. Hess, J.; Balasundaram, S.V.; Bakkemo, R.I.; Drula, E.; Henrissat, B.; Högberg, N.; Eastwood, D.; Skrede, I. Niche differentiation and evolution of the wood decay machinery in the invasive fungus Serpula lacrymans. ISME J. 2021, 15, 592-604. [CrossRef] 
44. Sturm, L.; Geißel, B.; Martin, R.; Wagener, J. Differentially regulated transcription factors and ABC transporters in a mitochondrial dynamics mutant can alter azole susceptibility of Aspergillus fumigatus. Front. Microbiol. 2020, 11, 1017. [CrossRef]

45. Zhan, C.; Bai, Z.; Wang, S.; Sun, Y.; Dai, X.; Liu, X.; Harvey, L.; McNeil, B.; Yang, Y. The Pichia pastoris transmembrane protein GT1 is a glycerol transporter and relieves the repression of glycerol on AOX1 expression. FEMS Yeast Res. 2016, 16. [CrossRef]

46. Li, X.; Yang, Y.; Zhan, C.; Zhang, Z.; Liu, X.; Liu, H.; Bai, Z. Transcriptional analysis of impacts of glycerol transporter 1 on methanol and glycerol metabolism in Pichia pastoris. FEMS Yeast Res. 2017, 18, 18. [CrossRef]

47. Ferreira, C.; van Voorst, F.; Martins, A.; Neves, L.; Oliveira, R.; Kielland-Brandt, M.; Lucas, C.; Brandt, A. A member of the sugar transporter family, Stl1p is the glycerol/H+ $\mathrm{H}^{+}$symporter in Saccharomyces cerevisiae. Mol. Biol. Cell 2005, 16, 2068-2076. [CrossRef] [PubMed]

48. Nobre, A.; Lucas, C.; Leão, C. Transport and utilization of hexoses and pentoses in the halotolerant yeast Debaryomyces hansenii. Appl. Environ. Microbiol. 1999, 65, 3594-3598. [CrossRef]

49. Jørgensen, T.R.; Vankuyk, P.A.; Poulsen, B.R.; Ruijter, G.J.G.; Visser, J.; Iversen, J.J.L. Glucose uptake and growth of glucose-limited chemostat cultures of Aspergillus niger and a disruptant lacking MstA, a high-affinity glucose transporter. Microbiology 2007, 153, 1963-1973. [CrossRef] [PubMed]

50. Stasyk, O.G.; Maidan, M.M.; Stasyk, O.V.; van Dijck, P.; Thevelein, J.M.; Sibirny, A.A. Identification of Hexose transporter-like sensor HXS1 and functional hexose transporter HXT1 in the methylotrophic yeast Hansenula polymorpha. Eukaryot. Cell 2008, 7, 735-746. [CrossRef]

51. Viigand, K.; Tammus, K.; Alamäe, T. Clustering of MAL genes in Hansenula polymorpha: Cloning of the maltose permease gene and expression from the divergent intergenic region between the maltose permease and maltase genes. FEMS Yeast Res. 2005, 5, 1019-1028. [CrossRef]

52. Magalhães, F.; Vidgren, V.; Ruohonen, L.; Gibson, B. Maltose and maltotriose utilisation by group I strains of the hybrid lager yeast Saccharomyces pastorianus. FEMS Yeast Res. 2016, 16. [CrossRef]

53. Lian, J.; Li, Y.; HamediRad, M.; Zhao, H. Directed evolution of a cellodextrin transporter for improved biofuel production under anaerobic conditions in Saccharomyces cerevisiae. Biotechnol. Bioeng. 2014, 111, 1521-1531. [CrossRef] [PubMed]

54. Vela-Corcía, D.; Srivastava, D.A.; Dafa-Berger, A.; Rotem, N.; Barda, O.; Levy, M. MFS transporter from Botrytis cinerea provides tolerance to glucosinolate-breakdown products and is required for pathogenicity. Nat. Commun. 2019, 10, 1-11. [CrossRef]

55. Yu, X.; Zheng, Y.; Xiong, X.; Chen, S. Co-utilization of glucose, xylose and cellobiose by the oleaginous yeast Cryptococcus curvatus. Biomass Bioenergy 2014, 71, 340-349. [CrossRef]

56. Chen, X.; Li, Z.; Zhang, X.; Hu, F.; Ryu, D.D.Y.; Bao, J. Screening of oleaginous yeast strains tolerant to lignocellulose degradation compounds. Appl. Biochem. Biotechnol. 2009, 159, 591-604. [CrossRef] [PubMed]

57. Belinchón, M.M.; Gancedo, J.M. Xylose and some non-sugar carbon sources cause catabolite repression in Saccharomyces cerevisiae. Arch. Microbiol. 2003, 180, 293-297. [CrossRef]

58. Portnoy, T.; Margeot, A.; Seidl-Seiboth, V.; Le Crom, S.; Ben Chaabane, F.; Linke, R.; Seiboth, B.; Kubicek, C.P. Differential regulation of the cellulase transcription factors XYR1, ACE2, and ACE1 Trichoderma reesei strains producing high and low levels of cellulase. Eukaryot. Cell 2011, 10, 262-271. [CrossRef] [PubMed]

59. Alazi, E.; Ram, A.F.J. Modulating transcriptional regulation of plant biomass degrading enzyme networks for rational design of industrial fungal strains. Front. Bioeng. Biotechnol. 2018, 6, 133. [CrossRef]

60. Schuerg, T.; Prahl, J.-P.; Gabriel, R.; Harth, S.; Tachea, F.; Chen, C.-S.; Miller, M.; Masson, F.; Matthew, M.; Brown, S.; et al. Xylose induces cellulase production in Thermoascus aurantiacus. Biotechnol. Biofuels 2017, 10,1-11. [CrossRef]

61. Granström, T. Metabolic flux analysis of candida tropicalis growing on xylose in an oxygen-limited chemostat. Metab. Eng. 2002, 4, 248-256. [CrossRef]

62. Hou, J.; Scalcinati, G.; Oldiges, M.; Vemuri, G.N. Metabolic impact of increased NADH availability in Saccharomyces cerevisiae. Appl. Environ. Microbiol. 2010, 76, 851-859. [CrossRef]

63. Christensen, K.E.; MacKenzie, R.E. Mitochondrial one-carbon metabolism is adapted to the specific needs of yeast, plants and mammals. Bioessays 2006, 28, 595-605. [CrossRef]

64. Bacher, A.D.; Eberhardt, S.; Fischer, M.; Kis, K.; Richter, G. Biosynthesis of vitamin B2 (riboflavin). Annu. Rev. Nutr. 2000, 20, 153-167. [CrossRef]

65. Luo, W.; Pant, G.; Bhavnasi, Y.K.; Blanchard, S.G., Jr.; Brouwer, C. Pathview Web: User friendly pathway visualization and data integration. Nucleic Acids Res. 2017, 45, W501-W508. [CrossRef] [PubMed]

66. Kratzer, S.; Schüller, H.-J. Transcriptional control of the yeast acetyl-CoA synthetase gene, ACS1, by the positive regulators CAT8 and ADR1 and the pleiotropic repressor UME6. Mol. Microbiol. 1997, 26, 631-641. [CrossRef]

67. Matsushika, A.; Goshima, T.; Hoshino, T. Transcription analysis of recombinant industrial and laboratory Saccharomyces cerevisiae strains reveals the molecular basis for fermentation of glucose and xylose. Microb. Cell Factories 2014, 13, 16. [CrossRef] [PubMed]

68. Zha, J.; Yuwen, M.; Qian, W.; Wu, X. Yeast-based biosynthesis of natural products from xylose. Front. Bioeng. Biotechnol. 2021, 9 . [CrossRef] [PubMed]

69. Atzmüller, D.; Ullmann, N.; Zwirzitz, A. Identification of genes involved in xylose metabolism of Meyerozyma guilliermondii and their genetic engineering for increased xylitol production. AMB Express 2020, 10, 78. [CrossRef]

70. Glenn, K.; Ingram-Smith, C.; Smith, K.S. Biochemical and kinetic characterization of xylulose 5-phosphate/fructose 6-phosphate phosphoketolase 2 (Xfp2) from Cryptococcus neoformans. Eukaryot. Cell 2014, 13, 657-663. [CrossRef] 
71. Bergman, A.; Hellgren, J.; Moritz, T.; Siewers, V.; Nielsen, J.; Chen, Y. Heterologous phosphoketolase expression redirects flux towards acetate, perturbs sugar phosphate pools and increases respiratory demand in Saccharomyces cerevisiae. Microb. Cell Factories 2019, 18, 1-13. [CrossRef]

72. Kwak, S.; Jin, Y.-S. Production of fuels and chemicals from xylose by engineered Saccharomyces cerevisiae: A review and perspective. Microb. Cell Factories 2017, 16, 1-15. [CrossRef]

73. Pontes, M.V.A.; Brandl, J.; McDonnell, E.; Strasser, K.; Nguyen, T.; Riley, R.; Mondo, S.; Salamov, A.; Nybo, J.; Vesth, T.C.; et al. The gold-standard genome of Aspergillus niger NRRL 3 enables a detailed view of the diversity of sugar catabolism in fungi. Stud. Mycol. 2018, 91, 61-78. [CrossRef] [PubMed]

74. Toivari, M.H.; Nygård, Y.; Penttilä, M.; Ruohonen, L.; Wiebe, M. Microbial D-xylonate production. Appl. Microbiol. Biotechnol. 2012, 96, 1-8. [CrossRef]

75. Wasserstrom, L.; Portugal-Nunes, D.; Almqvist, H.; Sandström, A.G.; Lidén, G.; Gorwa-Grauslund, M.F. Exploring D-xylose oxidation in Saccharomyces cerevisiae through the Weimberg pathway. AMB Express 2018, 8, 1-16. [CrossRef] [PubMed]

76. Bañares, A.B.; Nisola, G.M.; Valdehuesa, K.N.G.; Lee, W.-K.; Chung, W.-J. Understanding D-xylonic acid accumulation: A cornerstone for better metabolic engineering approaches. Appl. Microbiol. Biotechnol. 2021, 105, 5309-5324. [CrossRef]

77. Mishra, P.; Park, G.-Y.; Lakshmanan, M.; Lee, H.-S.; Lee, H.; Chang, M.W.; Ching, C.B.; Ahn, J.; Lee, D.-Y. Genome-scale metabolic modeling and in silico analysis of lipid accumulating yeast Candida tropicalis for dicarboxylic acid production. Biotechnol. Bioeng. 2016, 113, 1993-2004. [CrossRef]

78. Liu, Z.; Gao, Y.; Chen, J.; Imanaka, T.; Bao, J.; Hua, Q. Analysis of metabolic fluxes for better understanding of mechanisms related to lipid accumulation in oleaginous yeast Trichosporon cutaneum. Bioresour. Technol. 2013, 130, 144-151. [CrossRef] [PubMed]

79. Tehlivets, O.; Scheuringer, K.; Kohlwein, S.D. Fatty acid synthesis and elongation in yeast. Biochim. Biophys. Acta BBA Mol. Cell Biol. Lipids 2007, 1771, 255-270. [CrossRef]

80. Adrio, J.L. Oleaginous yeasts: Promising platforms for the production of oleochemicals and biofuels. Biotechnol. Bioeng. 2017, 114, 1915-1920. [CrossRef]

81. Ratledge, C.; Wynn, J.P. The biochemistry and molecular biology of lipid accumulation in oleaginous microorganisms. Int. Rev. Cytol. 2002, 51, 1-52. [CrossRef]

82. Wynn, J.P.; Ratledge, C.; Hamid, A.A.; Li, Y. Biochemical events leading to the diversion of carbon into storage lipids in the oleaginous fungi Mucor circinelloides and Mortierella alpina. Microbiology 2001, 147, 2857-2864. [CrossRef]

83. Kourist, R.; Bracharz, F.; Lorenzen, J.; Kracht, O.N.; Chovatia, M.; Daum, C.; Deshpande, S.; Lipzen, A.; Nolan, M.; Ohm, R.A.; et al. Genomics and transcriptomics analyses of the oil-accumulating basidiomycete yeast Trichosporon oleaginosus: Insights into substrate utilization and alternative evolutionary trajectories of fungal mating systems. mBio 2015, 6, e00918-15. [CrossRef] [PubMed]

84. Mayer, C.; Grummt, I. Ribosome biogenesis and cell growth: MTOR coordinates transcription by all three classes of nuclear RNA polymerases. Oncogene 2006, 25, 6384-6391. [CrossRef] [PubMed]

85. Phipps, K.R.; Charette, J.M.; Baserga, S.J. The small subunit processome in ribosome biogenesis-progress and prospects. Wiley Interdiscip. Rev. RNA 2010, 2, 1-21. [CrossRef]

86. Strunk, B.S.; Karbstein, K. Powering through ribosome assembly. RNA 2009, 15, 2083-2104. [CrossRef]

87. Tiukova, I.A.; Brandenburg, J.; Blomqvist, J.; Sampels, S.; Mikkelsen, N.; Skaugen, M.; Arntzen, M.Ø.; Nielsen, J.; Sandgren, M.; Kerkhoven, E.J. Proteome analysis of xylose metabolism in Rhodotorula toruloides during lipid production. Biotechnol. Biofuels 2019, 12, 137. [CrossRef] [PubMed]

88. Willis, S.D.; Hanley, S.E.; Beishke, T.; Tati, P.D.; Cooper, K.F. Ubiquitin-proteasome-mediated cyclin C degradation promotes cell survival following nitrogen starvation. Mol. Biol. Cell 2020, 31, 1015-1031. [CrossRef]

89. Pomraning, K.R.; Kim, Y.-M.; Nicora, C.D.; Chu, R.K.; Bredeweg, E.L.; Purvine, S.O.; Hu, D.; Metz, T.O.; Baker, S.E. Multi-omics analysis reveals regulators of the response to nitrogen limitation in Yarrowia lipolytica. BMC Genom. 2016, 17, 1-18. [CrossRef]

90. Kerkhoven, E.J.; Kim, Y.-M.; Wei, S.; Nicora, C.D.; Fillmore, T.L.; Purvine, S.O.; Webb-Robertson, B.-J.; Smith, R.D.; Baker, S.E.; Metz, T.O.; et al. Leucine biosynthesis is involved in regulating high lipid accumulation in Yarrowia lipolytica. mBio 2017, 8 , e00857-17. [CrossRef]

91. Maeda, Y.; Watanabe, R.; Harris, C.L.; Hong, Y.; Ohishi, K.; Kinoshita, K.; Kinoshita, T. PIG-M transfers the first mannose to glycosylphosphatidylinositol on the lumenal side of the ER. EMBO J. 2001, 20, 250-261. [CrossRef]

92. Sharma, C.B.; Knauer, R.; Lehle, L. Biosynthesis of lipid-linked oligosaccharides in yeast: The ALG3 gene encodes the Dol-P-Man: Man5GlcNAc2-PP-Dol mannosyltransferase. Biol. Chem. 2001, 382, 321-328. [CrossRef]

93. Bloch, J.; Pesciullesi, G.; Boilevin, J.; Nosol, K.; Irobalieva, R.N.; Darbre, T.; Aebi, M.; Kossiakoff, A.A.; Reymond, J.-L.; Locher, K.P. Structure and mechanism of the ER-based glucosyltransferase ALG6. Nat. Cell Biol. 2020, 579, 443-447. [CrossRef] [PubMed]

94. Vainauskas, S.; Menon, A. A conserved proline in the last transmembrane segment of Gaa1 Is required for glycosylphosphatidylinositol (GPI) recognition by GPI transamidase. J. Biol. Chem. 2004, 279, 6540-6545. [CrossRef]

95. Parlati, F.; McNew, J.A.; Fukuda, R.; Miller, R.; Söllner, T.H.; Rothman, J.E. Topological restriction of SNARE-dependent membrane fusion. Nat. Cell Biol. 2000, 407, 194-198. [CrossRef] [PubMed]

96. Mitrovic, S.; Ben-Tekaya, H.; Koegler, E.; Gruenberg, J.; Hauri, H.-P. The cargo receptors Surf4, endoplasmic reticulum-Golgi intermediate compartment (ERGIC)-53, and p25 are required to maintain the architecture of ERGIC and Golgi. Mol. Biol. Cell 2008, 19, 1976-1990. [CrossRef] [PubMed] 